\title{
القيادة الاستراتيجية وعلافتها بتحقيق الميزة التنافسية في \\ جامعة الطائف
}

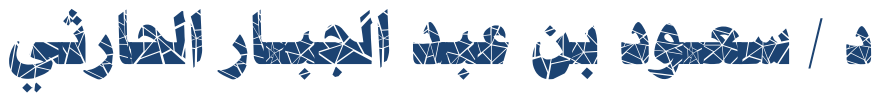

\section{أستاذ الإدارة التربوية المسياعد، كلية الملك عبد الله لللففاع \\ الجوي بـالطائف -المملكة العربية السعودية}

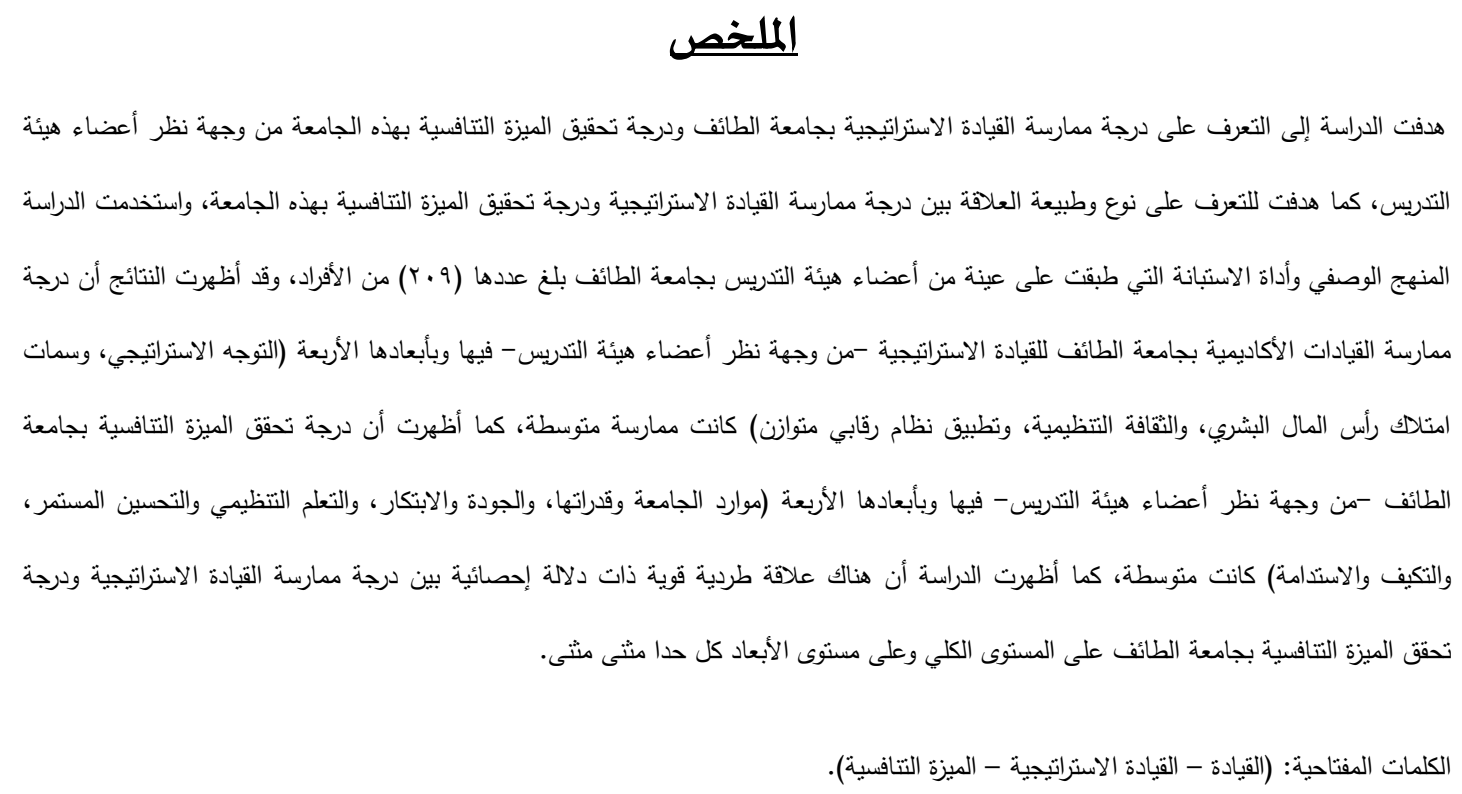

Abstract

The thesis aims at introducing two features of administration; The first one is the strategic leadership and the second is the competitive advantage within a survey made on Al- Taif University. The study uses a descriptive research method to evaluate these features on the teaching staff of Al-Taif University in order to find out the degree of practicing each feature throughout its aspects.

The aspects of the Strategic leadership are; strategic orientation, the features of human capital, corporate culture and applying a balanced super intendance system.

While the aspects of the competitive advantage are ; the resources and the abilities of the university, the quality and the creativity, organizing of education process and continuing improvement, and the last aspect is adapting of sustainability . 
The survey found out, by examining these aspects, that the degree of maintaining both features by teaching staff is average .

Finally, the thesis discusses the relationship between maintaining each feature on the other hand. The statistics indicates that there is a strong direct relationship between both features that is quite significant in general on one hand and by comparing features' aspects which mentioned previously on the other hand.

Keyword: (Leadership - Strategic leadership - Competitive advantage).

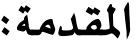

يعيش العالم اليوم في ظل سلسلة من المتغيرات الاقتصادية والسياسية والاجتماعية فرضت على المؤسسات بشكل عام ومؤسسات التعليم العالي بشكل خاص الاستعداد لمواجتها نظير الدور الكبير الذي تقوم به في قيادة المجتمعات، وتعد الجامعات أولى هذه المؤسسات بالاستعداد لمواجهة المتغيرات المتسارعة من خلال بناء توجه استراتيجي يرسم مستقبلها ويحقق أهدافها، وكل هذا يتطلب قيادة جامعية تتسم بثراء وعمق الثقافة ورحابة الفكر لمواجهة

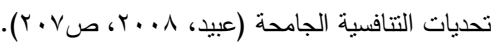

ومع الإيمان بحتمية القيادة في كل المؤسسات ودورها الكبير في رسم السياسات والأهداف والعمل على تحقيقها فإن مؤسسات التعليم العالي هي الأخرى بحاجة ماسَّة لقيادات فاعلة قادرة على تحديد التوجه الاستراتيجي لها؛ فالقيادة الاستراتيجية هي المسؤول الأول عن تحديد التوجه الاستراتيجي للجامعة الرامية لتحقيق الأهداف الاستراتيجية، لذلك فإن على القيادات الجامعية أن تكون قيادات استراتيجية حيث إن هناك اتفاقًا على أن القيادة الاستراتيجية هي عملية تتصل بتحقيق الميزة النتافسية (Hughes \& Beatty, 2005, P. 9). وأكدت العديد من الدراسات على أن للقيادة الاستراتيجية دورها الواضح في تتفيذ استراتيجية المنظمة من خلد مجموعة من الأدوار الدتفاعلة والتي ثأتي في مقدمتها إدارة موارد المنظمة بفعالية، والمساهمة في تأسيس الاتجاه الاستراتيجي، وتتشئة ثقافة تنظيمية فعالة، واستغلال الكفايات الجوهرية، واستخدام

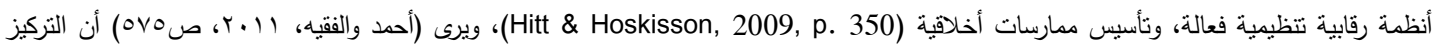
على القيادة الاستراتيجية يمتل ميزة تتافسية متواصلة ونجاحًا بعيدً المدى للمنظمة، لأنها تعتدد على السعي بالمنظمة لإنجاز مجموعة دائمة من الإمكانيات لتقديم قيمة مميزة للمستفيدين على المدى الطويل. ويرى (Hill \& Jones 2010) أن القيادة الاستراتيجية تتحور حول عملية صناعة استراتيجية المنظمة لابتكار الميزة التنافسية، ولزيادة الأداء بهذف زيادة قيمة الاستثمارات وأرباح المستقيدين.

إنَّ من أهم الأهداف التي تسعى القيادة الاستراتيجية لتحقيقها: استثمار الموارد الجوهرية للجامعة لتحقيق الميزة التنافسية التي لم تعد حِكرًا على المنظمات التجارية الربحية، بل أصبحت من أهم الأهداف الاستراتيجية لدى القيادات الجامعية التي تبحث لجامعاتها عن موطئ قدم بين الجامعات الرائدة والمتميزة، فالميزة التتافسية للجامعة ترتبط بشكل كبير بتوجهات قيادتها الاستراتيجية نحو إحداث التغيير الاستراتيجي الذي يقودها لتحقيق أهدافها خصوصًا مع ظهور

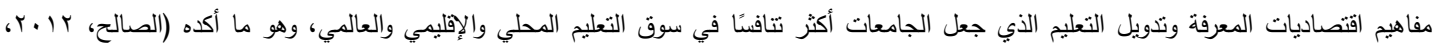


ص (1) أنَّ كثيرًا من المفاهيم التي كانت الجامعات في معظم دول العالم تتأى بنفسها عن التعامل معها، مثل مفاهيم السوق والعملاء والتتافبية، أصبحت قضايا ذات أهمية وضرورة للجامعات، وأصبح البحثُ عن فهمٍ أصيلٍ ومتعمٍٍ لمصطلح التنافسية بين الجامعات ومتطلبات تحقيقها عملاً أصيلاً وليس تكميليًا أو اختياريًا أمام الجامعات. ومما يزيد من أهمية التركيز على الميزة التتافية لدى قيادات الجامعات ارتباطها الكبير بتتافسية الدول فيما بينها وهو الأمر الذي أكده تقرير التنافسية العالمية (The Global Competitiveness Report, 2009: 05) حيث أكد أنَّ جودة التعليم العالي والتدريب تعتبر واحدة من الثتي عشرة ركيزة ثُقاس بها تتافسية الدول، كما أثنار الثقرير إلى أنَّ جودة التعليم العالي والتدريب أمر حاسم بالنسبة للاقتصاديات التي ترغب في الثقام في سلسلة القيمة إلى ما هو أكبر من عمليات الإنتاج والمنتجات البسيطة.

\section{مشكلة الدراسة:}

في ظل التوجه العالمي نحو اقتصاديات المعرفة وتدويل التعليم أصبحت القيادات الجامعية أمام تحدٍ كبيرٍ لقيادة جامعاتها نحو المزيد من التطور والتتافسية في سوق التعليم العالي المحلي والعالمي، خصوصًا مع ظهور التصنيفات العالمية للجامعات، والاهتمام الكبير بها، والذي فرض على هذه القيادات ضرورة صياغة استراتيجيات تتافسية لبناء واستدامة ميزة تتافسية في قطاع التعليم العالي. وقد أكدت دراسة عبد الديلمي (2017) ودراسة خليل (2017) قوة العلاقة التي تربط بين القيادة الاستراتيجية وبين بناء الميزة التتافسية في كل من الجامعات الأردنية والجامعات المصرية وهو ما يؤيد ضرورة دراسة العلاقة بين هذين المتغيرين في الجامعات السعودية، وهو ما أكلت دراسة احمد والفقيه (2011) ودراسة محد (2016) على أهمية القيادة الاستراتيجية في الجامعات كنموذج يقودها إلى تحقيق أهدافها المستقلية والتي يأني في مقدمتها التتافسية ، و أكدت دراسة الصالح (2012) على وجود درجة عالية من الإدراك لدى أعضاء مجالس الجامعات السعودية لأهمية بناء الميزة التنافسية فيها و أوصت بضرورة رفع المقدرة التتافسية للجامعات السعودية وتعزيز فرص اكتسابها للمزايا التتافسية ، و أظهرت دراسة هاشم (2017) أيضا أن هناك درجة عالية من الوعي بأهمية بناء الميزة التنافسية في جامعة الدمام ، و أظهرت دراسة اللوقان (2016) أيضا أهمية بناء الميزة التنافسية في جامعة حائل بالاعتماد على عدد من المنطلبات والتي يأني في مقدتها الهنطلبات التنظيمية ، ومن هذا الدنطلق تحاول الدراسة الحالية الإجابة السؤال الرئيس التالي: ما واقع ممارسة القيادة الاستراتيجية وعلاقتها بتحقيق الميزة التتافسية في "جامعة الطائف" من وجهة نظر أعضاء هيئة التنريس فيها؟ ويتفرع من السؤال الرئيس التساؤلات التالية: 1- ما واقع ممارسة القيادة الاستراتيجية بجامعة الطائف من وجهة نظر أعضاء هيئة التدريس؟ ץ- ما واقع تحقيق الميزة التتافسية بجامعة الطائف من وجهة نظر أعضاء هيئة التدريس؟ r- هل توجد علاقة ارتباطية ذات دلالة إحصائية عند مستوى الدلالة (a 20.05$)$ بين درجة ممارسة القيادة الاستراتيجية ودرجة تحقيق الميزة التتافسية بجامعة الطائف؟

\section{أهداف الدراسة:}

هدفت الدراسة الحالية إلىى:

1- التعرف على واقع ممارسة القيادة الاستراتيجية بجامعة الطائف من وجهة نظر أعضاء هيئة التدريس. 
r- التعرف على واقع تحقيق الميزة التتافسية بجامعة الطائف من وجهة نظر أعضاء هيئة التدريس. r- التعرف على نوع وطبيعة العلاقة بين درجة ممارسة القيادة الاستراتيجية ودرجة تحقيق الميزة التتافسية بجامعة الطائف.

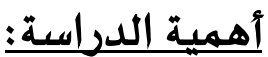

تتبع أهمية هذه الدراسة من أهمية دور القيادة الاستراتيجية في الجامعات لتحقيق أهدافها والتي يأني في مقدمتها الميزة التتافسية لها، ومن هنا يمكن أن

$$
\text { نلخص أهمية هذه الدراسة فيما يلي: }
$$

ا- ندرة الدراسات التي أجريت لبحث طبيعة العلاقة بين القيادة الاستراتيجية والميزة النتافسية حيث تسعى هذه الدراسة للوقوف على واقع العلاقة بين هذين الدخلين المهمين من مداخل النظوير والتحسين الذي تستهدفه الجامعات.

r- من المؤمل أن تُسهم نتائج هذه الدراسة في توجيه جهود القيادات الأكاديمية في جامعة الطائف لتعزيز نقاط القوة ومعالجة نقاط الضعف في أبعاد القيادة الاستراتيجية الأربعة (التوجه الاستراتيجي، سمات امتلاك رأس المال البشري، التقافة التظظيمية، تطبيق نظام رقابي متوازن)، وذلك لتحقيق الميزة التنافسية للجامعة. ب- يتوقع أن تسهم نتائج الدراسة في تقديم توصيات عملية تساهم في تطوير أداء القيادات الأكاديمية بجامعة الطائف لتحقيق الميزة التتافسية من خلال أبعادها الأربعة (موارد الجامعة وقدراتها، الجودة والابتكار، التعلم التنظيمي والتحسين المستمر، التكيف والاستدامة).

\section{حدود الدراسة:}

الحدود الموضوعية: اقتصرت حدود الدراسة الموضوعية على دراسة العلاقة بين القيادة الاستراتيجية بأبعادها الأربعة (النوجه الاستراتيجي، سمات امتلاك رأس المال البشري، الثقافة التظظيمية، تطبيق نظام رقابي متوازن) والميزة التتافسية بأبعادها الأربعة (موارد الجامعة وقدراتها، الجودة والابتكار ، التعلم التتظيمي والتحسين المستمر ، التكيف والاستدامة).

الحدود البشرية: اقتصرت الحدود البشرية على أعضاء هيئة التدريس في جامعة الطائف من (الذكور والإناث) برتبة (أستاذ، أستاذ مشارك، أستاذ مساعد)،

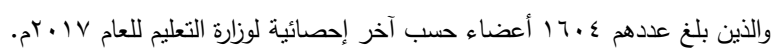
الحدود المكانية: جامعة الطائف بمحافظة الطائف، وقد تم تطبيق هذه الدراسة على جميع الكليات في المركز الرئيس لجامعة الطائف. الحدود الزمانية: تم تطبيق الدراسة في الفصل الدراسي الأول للعام الدراسي 9؟؟ اهـ - . ــ اهـ.

\section{مصطلحات الدراسة:}

القيادة:

ذكر ابن دريد (1987، ص190) في مادة (د ق و) قاد الرجل البعير وغيره ، يقود قودا - والجمع قود - وهو طول العنق في تطامن ، والقود ان ينقاد القاتل فيقتل بالذي قتله، والقياد حبل تقاد به الدابة . وعرفها العشماوي (1981، ص آبا) " بأنها فعل ديناميكي وقوة تهذف إلى تماسك المجموعة وعنصر توفيق يتحرك لتحقيق الأهداف المرسومة بفعالية 
وتعرفها الدراسة الحالية بأنها : القدرة على الثأثير في سلوك العاملين لتحقيق أهداف المنظمة سواء كانت هذه الأهداف قريبة أو بعيدة مع توفير كل متطلبات تحقيق هذه الأهداف .

القيادة الاستراتيجية:

عرَّفها (Mungonge, 2007) بأنها: "القدرة على التوقع والتصور ، والمحافظة على المرونة، وتمكين الآخرين من إحداث تغيير استراتيجي كضرورة". وعرَّفها (Pisapia, 2009, P. 7) بأنها: "القدرة على صناعة قرارات منطقية حول الغايات والأفعال والتكتيكات في بيئات الغموض وعدم التأكد". وتعرِّها الدراسة الحالية بأنها: قدرة القائد على تحديد التوجه الاستراتيجي للجامعة لتحقيق ميزة تتافسية بين مثيلاتها من خلال استثمار كل مواردها المتاحة.

التنافسبة :

في اللغة ذكر ابن منظور (د. ت، ص 0؛) أن التنافسية تثنق من تتافس أي تحاسد وتسابق وفي التنزيل ((وفي ذلك فليتنافس المتنافسون )) المطفقين بr ، ونقول سقيم النفاس أي أسقمته المنافسة والمغالبة ، وتقول أنفسهم أي أعجبهر وصار عندهم نفيسا ، ونافست في الثئ منافسة ونفاساً اذ رغبت فيه على

$$
\text { وجه المباراة في الكرم ، وتتافسوا فيه أي رغبوا ، وهو من الثئ النفبس الجيد في نوعه. }
$$

والتتافسية اصطلاحاً كما عرفها الخضري (2004، ص r Y) هي " استعمال الملكات والمواهب وقدات الإبداع والابتكار والتطوير على مستوى الفرد او المؤسسة ككل لاغتتام الفرص المتاحة ومصادر القوة لاكتثاف مجالات تحقيق تميز وتقوق على الآخرين " وتعرفها الدراسة الحالية بأنها استثمار القدرات المتاحة لتحقيق الأهداف المنشودة .

الميزة التنافسية:

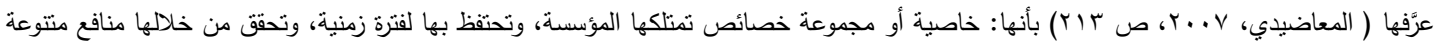
منها تحقيق التقوق على المنافسين. وعرَّها (عساف، 10 • r، ص ـ (1) بأنها: مهارة أو تقنية أو مورد متميز يتيح للمؤسسة أداء أعمالها بالثكل الذي يصعب على منافسيها تقليده، وذلك من خلا أداء الأنثطة بأدنى مستوى من التكلفة. وتعرفها الدراسة الحالية بأنها: مجموعة الخصائص والسمات (المادية والبشرية) التي تمتلكها الجامعة، وتتميز بها عن مثيلاتها، وتحقق لها التميز والتقرد في تحقيق أهدافها.

\section{الإطار النظري واللراسيات السيابقة}

\section{أولاً: القيادة الاستراتيجية:}

القيادة ظاهرة اجتماعية؛ فلا قيمة للقائد بدون تابعين وبدون ثأثثر في سلوكهم نحو تحقيق أهداف منظمتهم؛ وربط أهداف القيادة وخططها بالمدى البعيد يستلزم تبني مفاهيم ومناهج الإدارة الحديثة التي تحقق التميز التنافسي للمنظمة ككل، والقيادة الاستراتيجية كمفوم حديث في الأدب الإداري ذات جذور من مفاهيم الإدارة العسكرية إلا التغيرات المتسارعة فرضت على المنظمات الاستفادة من هذا المفهوم في تحسين أدائها. 


\section{مفهوم القيادة الاستراتيجية:}

تعددت مفاهيم القيادة الاستراتيجية لدى كتاب الإدارة وباحثيها؛ فكل نظر لها من زاوية اختصاصه واهتماماته، فعرفها (Mungonge. 2007) بأنها:

$$
\text { القدرة على التوقع والتصور ، والمحافظة على المرونة، وتمكين الآخرين من إحداث تغيير استراتيجي كضرورة. }
$$

وعزَّفها (Hilcoat, R. A, 1995, p. 153) بأنها: تلك الأفعال التي تركز بشكل كبير على تحديد التوجه طويل الأمد، والروئية الاستراتيجية، وإيصال هذه الروية إلى الجهات ذات العلاقة والولاء، والقوة اللازمة لإدراك هذه الرؤية وتحقيقها، وإلهام الآخرين للتوجه صوب الاتجاه الصحيح. وعرَّها (جاد الرب، r ب .r، ص 9؟) بأنها: القدرة على التخيل والتصور المستقبلي، وأيضا بناء المرونة، ودعم الآخرين نحو خلق التغيير الاستراتيجي

$$
\text { الضروري والمطلوب في المنظمة. }
$$

ويرى (عبد الدليمي، V • r، ص • (1) أن القيادة الاستراتيجية هي القيادة التي لديها القدرة الفائقة على تكوين الرؤية المستقبلية، ورسم صورة واضحة لمستقبل المنظمة، بالاعتماد على التفكير الاستراتيجي والإبداعي، ورسم سيناريوهات وخطط استراتيجية، مع القدرة في التأثير في الآخرين، وإقناعهم بتنبي

$$
\text { الرؤية الاستراتيجية، واستنهاض هممه نحو التنفيذ الاستراتيجي الفعال. }
$$$$
\text { 1- قدرة القائد على تكوين الرؤية الاستراتيجية التي تحقق للمنظمة أهدافها بالاعتماد على أساليب التفكير الاستراتيجي. }
$$

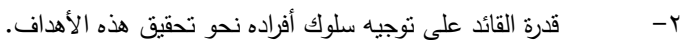

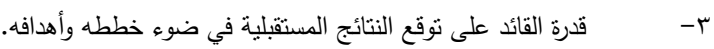

ع- قدرة القائد على ابتكار أساليب جديدة لإنجاز المهام الوظيفية لأفراده نخذم الخطة الاستراتيجية، وتحقق أهدافها بأقل تكلفة في الوقت والجها

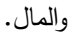

\section{أهمية القيادة الاستراتيجية:}

ترتبط أهمية القيادة الاستراتيجية بمستقبل المنظمة لكونها مصدر رسم السياسات والرؤى المستقبلية، ويؤكد (جاد الرب، 2012، ص 492) أن القيادة

الاستراتيجية تساهم في بناء وتشييد فرق العمل وبخاصة ما تدار ذاتتًا، وتمكين العاملين، ويناء السلوك الأخلاقي، ووضع الروئة والثقافة التنظيمية، وزيادة

$$
\begin{aligned}
& \text { القدرات التتظيمية، ويذكر (خليل، 2017، ص 131) أن أهمية القيادة الاستراتيجية تكمن فيما يلي: } \\
& \text { 1- بناء ثقافة تنظيمية فعالة تتميز بالمرونة والقدرة على مواجهة التغيير وإدارته. }
\end{aligned}
$$

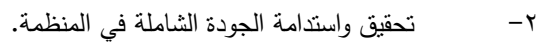

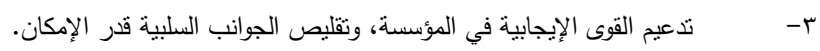

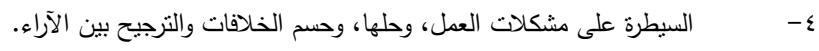

$$
\begin{aligned}
& \text { o }
\end{aligned}
$$

ويرى (المربع، rا.ب) أن أهمية القيادة الاستراتيجية تعود إلى أنها مصدر الإبداع والابتكار، كما أنها تلعب دورًا كبيرًا في التوفيق بين الأطراف المتعارضة داخل المنظمة، فهي تحقق التوازن الاستراتيجي بين النطلعات والحاجات المتقاطعة. 
ويؤكد (Bass, 2007 p. 36) أن القيادة الاستراتيجية تعزز الالتزام والمشاركة، وتؤكد النموذج الأخلاقي في العلاقات المؤسسية الداخلية، كما أنها بمثابة الممثل للمؤسسة والمفاوض عنها في التعامل مع الوكالات والهيئات والمؤسسات الخارجية ذات الصلة. وعن أهمية ممارسة القيادة الاستراتيجية في الجامعات يرى (أحمد والفقيه (1 +r، صع مه) أنها تمكنها من البقاء والمنافسة -خصوصا الناشئة منهاوذلك من خلال استجابتها الاستراتيجية للبيئة المجتعية المحيطة بها بما تحويه من اتجاهات وتطبيقات، ومن خلال سعيها لمواجهة التحديات المعقدة والمتثابكة التي تعترض سيلها بحلول استراتيجية لا تتعامل مع اللحظة الراهنة، وإنما مع التوجه المستقبلي، وكنلك من حاجتها لتجنيد هياكلها البشرية والأكاديمية والإدارية لبناء القدرة الفعالية المؤسسية. ويرى الباحث أن أهمية القيادة الاستراتيجية في الجامعات تأني من عدة أمور أهمها: 1- القيادة الاستراتيجية هي المسؤولة عن بناء رؤية ورسالة المنظمة وتحديد مستقبلها المنشود. r- استثمار موارد وقدرات المنظمة -المادية والبشرية- لتحقيق أهدافها الاستراتيجية. r- بناء الثقافة التنظيمية الداعمة للإبداع والابتكار والإنجاز .

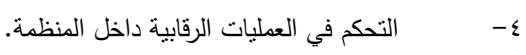

\section{أبعاد القيادة الاستراتيجية:}

للقيادة الاستراتيجية مجموعة من الأبعاد كلما أحاطت بها كلما كانت قريبة من تحقيق أهدافها الاستراتيجية خصوصا إذا ما تمت صياغة هذه الأبعاد وتتفيذها ومتابعتها بثكل متكامل يضمن للجامعات تحقيق الريادة والميزة التتافسية. ومن خلال مراجعة الأدبيات العلمية لعلم الإدارة تعددت النماذج العلمية والتي تصنف أبعاد القيادة الاستراتيجية ومن أشهرها نموذج (Hitt \& Ireland) والتي أوردها (Bass, 2007, p. 42) حيث يرى أنَّ ممارسة القيادة الاستراتيجية الفعالة يتم من خلال الأبعاد التالية:

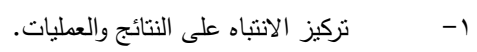

$$
\begin{aligned}
& \text { ب- السعي لاكتساب وترقية المعرفة. }
\end{aligned}
$$

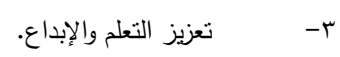

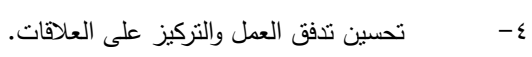

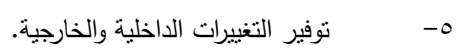

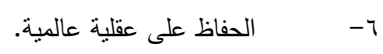

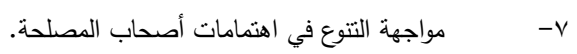

$$
\begin{aligned}
& \text { 1- - البناء للمدى الطويل مع تلبية الاحتياجات على المدى القصير. } \\
& \text { 9- تطوير رأس المال البشري. }
\end{aligned}
$$

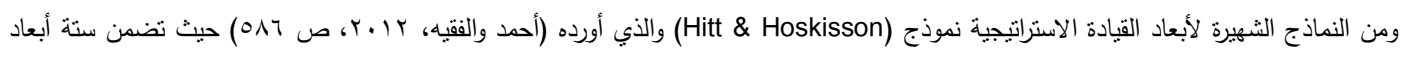

$$
\text { - } \quad \text { - }
$$

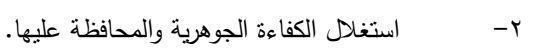




$$
\text { ؟- }
$$

وقََّمَ م-16) نموذجًا للقيادة الاستراتيجية شمل أربعة عناصر هي: ( البعد التحويلي و البعد الإداري و البعد السياسي و البعد

$$
\text { ومِنْ خِلال ما سبق يتبنى الباحث في هذه الدراسة أربعة أبعاد رئيسة للقيادة الاستراتيجية هي: }
$$

فالتوجه الاستراتيجي يعتد على بناء الرؤية الاستراتيجية المستقبلية للمنظمة ورسالتها وأهدافها وسبل تحقبقهامع بناء تصور شامل للبيئة الداخلية

$$
\text { والخارجية ولها قدرة عالية على الاستفادة من التجارب العالمية في هذا المجال. }
$$

والنوجه الاستراتيجي يعتبر حاليا أحد الأسس التي تننى عليها تتافسية الجامعات والذي تتزجمه شخصية القائد الاستراتيجي الهلهم والذي يحفز فريق العمل

$$
\text { لتحقيق الأهداف المنشودة. }
$$

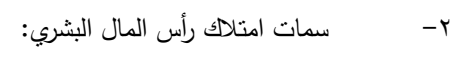

عرف (Youdt \& M.A.Snell,1996, p: 335) رأس المال البشري بأنه: مجموعة من الأفراد الذين يمتلكون مهارات ومعارف تُسهم في زيادة القيمة

$$
\text { الاقتصادية لمنظمات الأعمال. }
$$

فامتلاك رأس المال البشري أحد أهم الأبعاد الاستراتيجية للمنظمة في العصر الحالي، فهو رأس مال غير ملموس لكنه يقدّر بالملايين إذا ما تم استغلاله بطريقة مناسبة لتحقيق أهداف المنظمة، ففي الدول المتقدمة ينظر إليه على أنه مورد من أهم موارد المنظمات واصل من أهم أصولها، ويرى (النقاز،

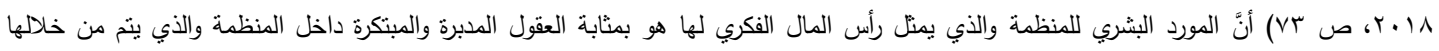
ابتكار السلع والخدمات الجديدة التي من خلالها يتم اقتتاص الفرص التسويقية المتاحة والتي تعود بالنفع على المنظمة.

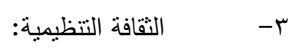
تلعب الثقافة التنظيمية دورًا مهمًا في تحديد الدسار الاستراتيجي للمنظمات فهي مجموعة من الممارسات والقيم التي تعكس الأداء الفعلي للمنظمة، وتوجه

$$
\text { سلوك أفرادها نحو تحقيق الأهداف الهنشودة. }
$$

يأتي تطبيق نظام رقابي متوازن داخل المنظمات ضمن أهم أبعاد القيادة الاستراتيجية؛ فالعملية الرقابية هي تغذية راجعة يتم الاستفادة منها في تطوير

الأداء ومراجعة الانحرافات التي تخرج عن مسار الخطط، وهي من أهم الوظائف القيادية للقائد الاستراتيجي إذا مارسها وفق آلياتها وأساليبها العلمية.

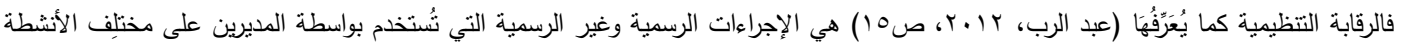
التظظيمية، وذلك بهدف مقارنة الأداء الفعلي بالأداء المستهدف، كما أنها تساعد في بناء مصداقية وثقة لدى القائد الاستراتيجي، وتدعم وتعزز دوره في التغيير الاستراتيجي الهادف لزيادة القيمة بالنسبة لأصحاب المنافع. 


\section{ثُانيا: الميزة التتافسية:}

تُعتبر الميزة التتافسية في الوقت الحالي من أهم الأسلحة التي تستخدمها المنظمات بشكل عام والجامعات بشكل خاص في مواجهة التحديات المتسارعة، خاصة وقد ارتبطت في الآونة الأخيرة ارتباطًا وثيقًا بظهور التصنيفات الدولية للجامعات، فأصبحت الجامعات كوبلا استثناء- تبحث عن تصنيف متقدم في هذه التصنيفات، الأمر الذي يحتم عليها تحسين مدخلاتها وعملياتها بشكل شامل لتصل إلى هدفها المنشود. وقد ظهرت التصنيفات العالمية للجامعات في عام 9 ام عندما بدأ تصنيف برامج الدراسات العليا في الولايات المتحدة الأمريكية لتستمر بعدها المحاولات لتصنيف مؤسسات التعليم العالي سواء من جانب الباحثين أو المؤسسات البحثية. ويؤكد (Washter \& Kemp, 2010, p: 6-7 أن هناك مجموعة من الخصائص التي يجب أن تمتلكها الجامعة لتصبح ذات مستوى متميز عالميًّا، ومن أهمها استقطابُ أعضاءٍ هيئة تدريسٍ وطلاب وموظفين متميزين، وكذلك قدرتها على نتويع مصادرها التمويلية من خلا التمويل الحكومي والفوز بالمناقصات التنافسية والعقود الاستشارية، وكذلك إيرادات الرسوم الدراسية والأوقاف والهِيَّات، فالجامعات التي لا تقفُ على مصدر واحد للتمويل هي الجامعات التي تتمتع بحرية أكاديمية أعلى دون قيود أيديولوجية أو سياسية على خططها وأنشطتها. إن امتلاك الجامعة للميزة التتافية حاليا هو امتلاك لمصدر قوة بساعدها في تحقيق أهدافها وتوسيع أنشطتها وكبح جماح المنافسين في التوسع في محيطها.

\section{مفهوم الميزة التتافسية:}

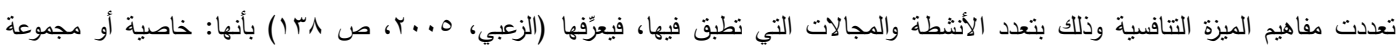
خصائص نسبية تتفرد بها المؤسسة ويمكنها الاحتفاظ بها لمدة طويلة نسبيًا نتيجة صعوبة محاكاتها، وتحقق خلد تلك الددة المنفعة لها، وتمكنها من التفوق على المنافسين فيما تقدمه من خدمات وسلع.

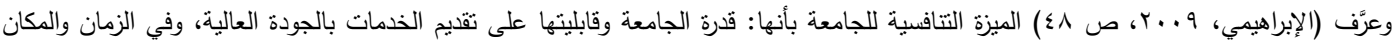

الملائمين، وبأقل التكاليف، مما يساعد الجامعة على الاستمرار في تحقيق أهدافها، في ظل وجود جامعات منافسة، مع قناعتها بأنَّ البقاء للأفضل.

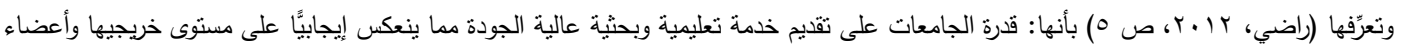
هيئة التدريس بها، ويكسبهم قدرات ومميزات تتافسية في سوق العمل بمستوياته المختلفة، وينعكس على ثقة المجتمع فيها، والتعاون معها، مما يزيد إقبال الطلاب للالنحاق بها.

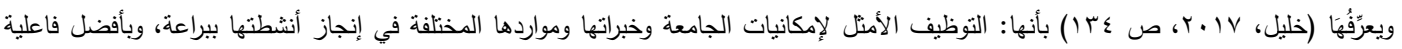
وأقل تكلفة، وبشكل يحقق منافع متتوعة، وقيمة مضافة لدخرجاتها، نسبة إلى منافسيها، مما ينعكس على ثقة المجتمع فيها، ويؤدي إلى تفردها. وتعرِّفُها الدراسة الحالية بأنها: قدرة الجامعة على استثمار مواردها المتتوعة في سبيل تقديم خدماتها بشكل متميز عن مثيلاتها مما يزيد من ثقة المستفيدين فيها؛ خاصة والجامعات السعودية تتلقى دعمًا حكوميًا كبيرًا، وتمنلك بنَى تحتية متميزة الأمر الذي يؤهلها لإيجاد ميزات تتافسية كثيرة تساهم في تحقيق أهدافها، والتي من أهمها بناء قدرات وطنية قادرة على سد الاحتياج في سوق العمل السعودي، والمساهمة في تتمية بلادهم.

\section{خصائص الميزة التتافسية:}

تنفق كثيرٌ من الأدبيات على عددٍ من الخصائص الأساسية للميزة التنافسية والتي يأتي في مقدمتها الاستمرارية والتجديد والمرونة، فيما أضافت العديد من المصادر خصائص أخرى برون أنها تُسهم في تحسين الميزات التنافسية في الجامعات: 


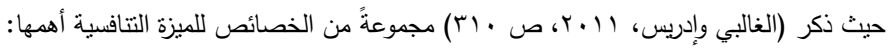

$$
\begin{aligned}
& \text { 1- - - } \\
& \text { r- - أن تتسم الميزات التنافسية بالنسبية مقارنة بالمنافسين. }
\end{aligned}
$$

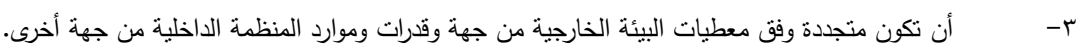

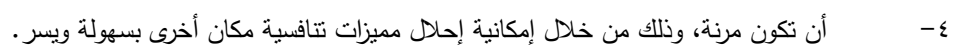

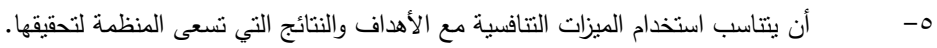

$$
\begin{aligned}
& \text { وأورد (الدوري وأحمد، } 9 \text {. . r، صجr ) مجموعة من الخصائص أهمها: } \\
& \text { 1- أن الميزة التتافسية تقدم دعمًا هامًًا يُساهم في نجاح الأعمال. } \\
& \text { r - أنَّ الميزة النتافسية تتصف بالديمومة والقوة وصعوبة تقليد المنافسين لها. }
\end{aligned}
$$

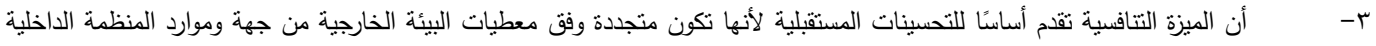

$$
\begin{aligned}
& \text { من جهة أخرى. }
\end{aligned}
$$

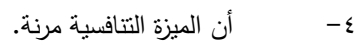

$$
\begin{aligned}
& \text { ه- أن الميزة التنافسية تحدد بالاعتماد على حاجات ورغبات الزبون. } \\
& \text { وتتفق الدراسة الحالية مع ما ذهبت إليه الدراسات السابقة، وتضيف إليها عددًا من الخصائص أهمها: } \\
& \text { 1- أن تكون الميزات التنافسية ميزات حديثة، ومتجدة، وتوضع ضمن خطط الجامعة الاستراتيجية. }
\end{aligned}
$$

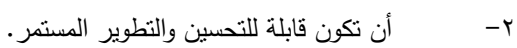

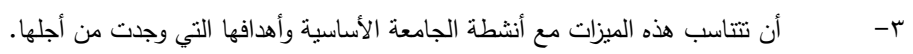

$$
\begin{aligned}
& \text { ع - - أن تكون هذه الميزات واقعية، يمكن أن تطبق على أرض الواقع، وتخدم مستفيدي الجامعة، وتحقق لهم الرضا. }
\end{aligned}
$$

\section{أبعاد الميزة التتافسية:}

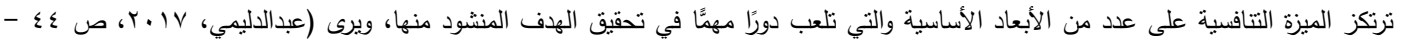

V乏 أن للميزة التنافسية خمسة أبعاد رئيسة، هي:"جودة الخدات و التكلفة و المرونة و الوقت والتسليم والإبداع."

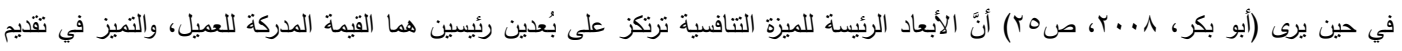

$$
\text { السلعة التي لا يسنطيع المنافسون تقليدها أو عمل نسخة منها. }
$$

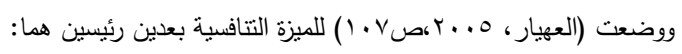

ا- التكلفة الأقل، وتعني القدرة على تصميم وتصنيع وتسويق منتجاتها بأقل تكلفة مقارنة بالمنظمات الأخرى مما يؤدي إلى تحقيق نتائج

$$
\text { أكبر. }
$$




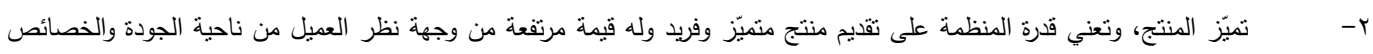

$$
\text { بعد البيع. }
$$

\section{أما الدراسة الحالية فترتكز على أربعة أبعاد رئيسة، هي:}

موارد الجامعة وقدراتها:

حيث تلعب موارد الجامعة (المادية والبشرية) دورا كبيرا في تميزها عن منافسيها، فكلما ارتقعت هذه الموارد وهذه القدرات كلما زادت تتافسية

$$
\begin{aligned}
& \text { الجامعة وفرصها في الاستحواذ على العملاء. } \\
& \text { ب }
\end{aligned}
$$

أصبحت الجودة والابنكار في المنتجات من أهم أبعاد الميزة التنافسية في الوقت الحالي نظرا للأهمية الكبيرة لها في البقاء والاستمرار في المنافسة، فالجودة تعني ثقة المستفيد بمخرجات الجامعة، والابتكار يعني تجديد وتحديث البرامج والخدمات بما يلائم احتباجات سوق العمل.

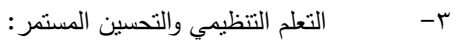

يعتمد التعلم التظظيمي على ما توفره الجامعة من معلومات وبيانات وإمكانيات ومعارف وخبرات للعاملين فيها تُشهم بشكل كبير في تطوير آليات العمل، مما يجعل التعلم التتظيمي والتحسين المستمر من أهم الأبعاد التي يمكن أن تساهم في تتافسية الجامعة خصوصا إذا ارتبطت مع التحسين المستمر للخدمات من خلال التدريب والتأهيل والاستقطاب.

$$
\text { ع }
$$

يعتبر التكيف مع المتغيرات المحيطة بالجامعة بصورة سريعة من أهم المميزات التي تتميز بها الجامعة، فأيا ما تكون هذه التغيرات إيجابية أو سليبة فعلى الجامعة أن تستفيد منها وتطور استراتيجياتها لمجاراتها. كما أن من المهم أن تكتسب الجامعة ثقافة الاستمرارية والاستدامة التنافسية من خلال المحافظة على مستوى الخدمات التي تقدمها، وجودة

\section{الدراسات السيقة}

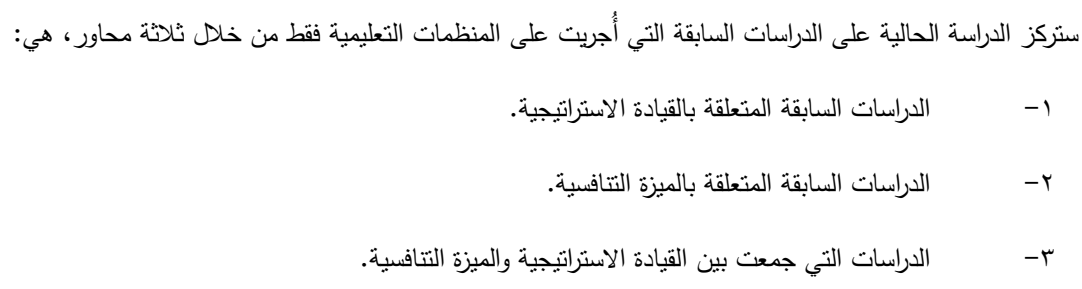

\section{أولاً: الدراسات السابقة المتعلقة بالقيادة الاستراتيجية:}

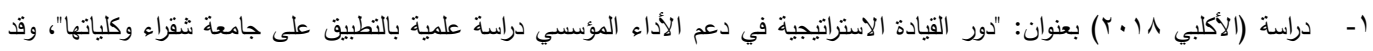
هدفت الدراسة إلى التعرف على خصائص وممارسات القيادة الاستراتيجية في جامعة شقراء، والوصول إلى واقع الأداء المؤسسي في جامعة شقراء، واستكثاف نوع ووظيفة العلاقة بين مدى وضوح النوجه الاستراتيجي في جامع شقراء وعناصر دعم ممارسة القيادة الاستراتيجية. 
وأظهرت الدراسة أن هناك ضعفًا في الخطوات العملية والإجراءات التتفيذية التي تمارسها الجامعة للاستفادة من الكفاءات المتميزة واستقطاب الكفاءات، كما أظهرت أن هنالك في إدراك منسوبي الجامعة لدرجة الاستخدام الرشيد للصلاحيات، وأظهرت أن نظم الاتصال وتبادل المعلومات ونظام التقارير ودوريتها في الجامعة وكلياتها لا يتوافق مع مقومات ومنظلبات الأداء المؤسسي، كما أن استثمار دور القيادات الاستراتيجية في الجامعة محدود. دراسة (الزهراني ^1 ا.ب) بعنوان: "القيادة الاستراتيجية وأثرها في تطوير قدرات التعلم التنظيمي: دراسة ميدانية على جامعة أم القرى"، وقد هدفت الدراسة إلى التعرف على درجة ممارسة القيادة الاستراتيجية بأبعادها الأربعة (الإداري، التحويلي، السياسي، الأخلاقي) في جامعة أم القرى، وتحديد درجة توافر قدرات التعلم التنظيمي بنوعيها (قدرات التعلم التكيفي، وقدرات التعلم التوليدي) في الجامعة، بالإضافة إلى تحليل واختبار تأثير أبعاد القيادة الاستراتيجية على تطوير قدرات التعلم النتظيمي، ولتحقيق أهداف الدراسة استخدم الباحث المنهج الوصفي التحليلي، واستعان

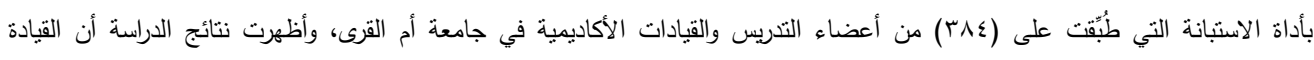
الاستراتيجية تمارس بدرجة عالية، وأنَّ قدرات التعلم التنظيمي التكيفي متوفرة بدرجة متوسطة وبنسبة أعلى من توفر قدرات التعلم التنظيمي التوليدي، وأن هناك علاقة موجبة (طردية)، تأثيرًا ذا دلالة إحصائية لأبعاد القيادة الاستراتيجية في تطوير كل قدرات التعلم التنظيمي، وقد كان البعد التحويلي للقيادة الاستراتيجية هو الأكثر تأثيرًا، وقد أوصت الدراسة بضرورة تنبي النموذج الذي اقترحته الدراسة.

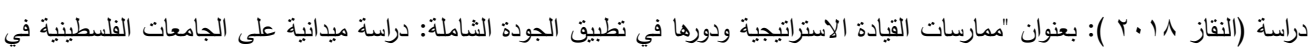
قطاع غزة"، وقد هدفت الدراسة إلى التعرف على مدى مساهمة ممارسات القيادة الاستراتيجية في تحقيق الجودة الثاملة في الجامعات الفلسطينية في قطاع غزة، واستخدم الباحث المنهج الوصفي التحليلي وجمع البيانات الرئيسة للدراسة باستخدام قائمة الاستقصاء، كما استخدم المقابلة الثخصية لبعض القيادات الاستراتيجية في الجامعات، وبلغت عينة الدراسة . بr فردًا من العاملين في جامعات قطاع غزة، وهي جامعة الأفصى، وجامعة الأزهر ، والجامعة الإسلامية، وأظهرت الدراسة أن هناك علاقة إحصائية بين تطبيق الجودة الثاملة وبين ممارسات القيادة الاستراتيجية مجتمعة، كما أظهرت الدراسة وجود تأثير مهم ذي دلالة إحصائية لأبعاد وممارسات القيادة الاستراتيجية في الجامعات الفلسطينية في قطاع غزة، وكانت طبيعة العلاقة طردية موجبة على تطبيق الجودة الثاملة باستثاء ممارستين، هما استثمار القرات والمواهب الاستراتيجية والرقابة تتظيمية المتوازنة فكانت طبيعة التأثير سلبيّة. ـ - دراسة (محد 17 • ب) بعنوان: "القيادة الاستراتيجية المحددة للفاعلية الإدارة العليا في جامعة النهرين"، وقد هدفت الدراسة إلى التعرف على مستوى أنماط القيادة الاستراتيجية لدى أفراد الإدارة العليا في جامعة النهرين، والتعرف على مستوى نأثير هذه الأنماط على فاعلية الإدارة العليا، وأظهرت الدراسة وجود ضعف نسبي في مهارة التنفيذ، وأيضا ذات الصلة بأنماط القيادة الاستراتيجية، مع تفوق واضح لمهارة الروئة، تليها مهارة التركيز ، كما أظهرت الدراسة تميز فريق الإدارة العليا بجامعة النهرين في مجال إنجاز المهام، وقد أوصت الدراسة بضرورة اعتماد أنماط القيادة الاستراتيجية باعتبارها من العوامل المهمة في اختيار القيادات الجامعية.

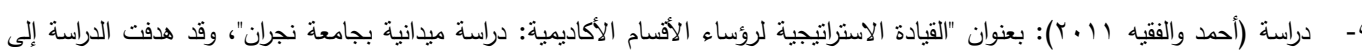
تحديد أبعاد القيادة الاستراتيجية، ومقوماتها، وضروراتها للقيادات الأكاديمية، والتعرف على درجة ممارسة رؤساء الأفسام الأكاديمية في جامعة نجران لأبعاد القيادة الاستراتيجية، وتحديد نأثير التخصص والجنس والجنسية والرتبة الأكاديمية على استجابات أعضاء هيئة التدريس حول مدى ممارسة رؤساء الأقسام الأكاديمية بجامعة نجران لأبعاد القيادة الاستراتيجية، واستخدمت الدراسة الأسلوب الوصفي المسحي وأداة الاستبيان التي 
وزعت على 10r عضوًا من أعضاء هيئة التدريس بجامعة نجران، وأظهرت الدراسة أن ممارسة رؤساء الأفسام الأكاديمية للبعد الأخلاهي جاء بدرجة كبيرة ، ثم جاء بعده البعد الإداري بدرجة ممارسة كبيرة، ثم البعد التحويلي بدرجة ممارسة متوسطة، وفي المرتبة الأخيرة البعد السياسي بدرجة ممارسة متوسطة، وأوصت الدراسة بضرورة ربط استراتيجيات العمل برؤية وقيم القسم، وضرورة تعبئة وتكامل القرات والإمكانات المادية والموارد عبر كل المستويات لإنجاز الأهداف الاستراتيجية. دراسة (Ussahawani tihakit 2011) بعنوان: "اثز اعتدال القيادة الاستراتيجية والتعلم التنظيمي والابتكار النتظيمي على الأداء"، وهدفت هذه الدراسة للتعرف على أثز القيادة الاستراتيجية والتعلم التنظيمي والابتكار التنظيمي على أداء الأعمال الإلكترونية بتايلاند، وعلاقتها من خلال البيئة التتافسية، واستخدمت الدراسة المنهج الوصفي وأداة الاستبانة معم ال ا مديرًا، وأظهرت الدراسة أن للقيادة الاستراتيجية علاقة إيجابية كبيرة بالأداءوالابتكار التنظيمي، وأن للابتكار التنظيمي علاقة إيجابية مع التعلم التتظيمي ومع الأداء، وأن التعلم التنظيمي ليس له أي تأثير على الأداء، وكذلك البيئة التتافسية ليس لها أي تأثير على التعلم التنظيمي والابتكار النتظيمي والأداء. ثانيًا: الدراسات السابقة المتعلقة بالميزة التنافسية:

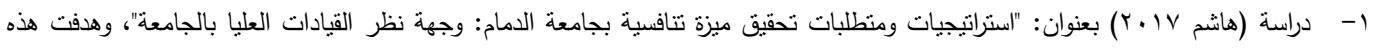
الدراسة إلى الكثف عن مفهوم الميزة التتافسية من وجهة نظر القيادات العليا بجامعة الدمام والذي يفترض أن تتبناه الجامعة، وتحديد أفضل وأنسب الاستراتيجيات التي تمكن الجامعة من التميز والمنافسة، وتحديد مجالات النتافس ومتطلباتها من وجهة نظر القيادات العليا في الجامعة. وقد اعتدت الدراسة على المنهج الوصفي وعلى الاستبانة كأداة لجمع البيانات والمعلومات من عينة من القيادات العليا بالجامعة بلغت . عضوًا، بنسبة ^.^^؛ \% وتوصلت الدراسة إلى عدة نتائج، أهمها: ( ) اتفاق نسبة r.به \% من عينة البحث على أن "قدرة الجامعة على استثمار كافة الإمكانات البشرية والمادية لديها لتقديم خدمة متميزة عن الجامعات الأخرى المنافسة، وهو المفهوم الذي يجب أن تتبناه جامعة الدمام لتحقيق ميزة تتافسية. r) جاء مجال التعلم والتعليم في الترتيب الأول لمجالات تحقيق ميزة تتافسية لجامعة الدمام، وهو الأهم، وله الأولوية الكبرى، يليه في التزتيب والأهمية مجال البحث العلمي، ثم باقي المجالات. r) جاءت استراتيجية "التمايز والاختلاف عن الجامعات المنافسة" في الترتيب الأول، ولها الأهمية والأولوية في تنبيها في جامعة الدمام لتحقيق ميزة تنافسية، ويليها في التزتيب الثاني في الأهمية التحالفات الاستراتيجية، ثم باقي الاستراتيجيات. ؟) اتفقت نسبة كبيرة من عينة البحث على أهمية جميع المنطلبات الدذكورة لتحقيق ميزة تتافسية لجامعة الدمام بدرجة كبيرة وإن اختلفت في الترتيب، لكن الفروق بينها في الترتيب قليلة جدًا، ويدل على وجود درجة كبيرة من الوعي لاى عينة البحث بمتطلبات التنافسية في المجالات المذكورة.

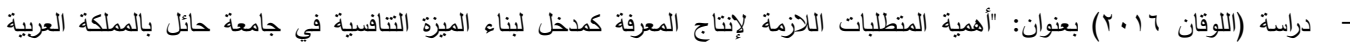
السعودية"، وهدفت الدراسة إلى التعرف على درجة أهمية المنطلبات اللازمة لإنتاج المعرفة لبناء الميزة التنافسية في جامعة حائل من وجهة نظر القيادات الأكاديمية فيها، ومعرفة الفروق ذات الدلالة الإحصائية من وجهة نظرهم حول درجة أهمية المنطلبات تُعزًا لاختلاف متغيرات الدراسة، وقد استخدمت الدراسة المنهج الوصفي المسحي وأداة الاسنبانة لجمع البيانات والتي وزعت على عينة الدراسة البالغ عددها هبا قائدًا أكاديميًا، حيث أظهرت النتائج أن درجة أهمية المنطلبات اللازمة لإنتاج المعرفة كمذل لبناء الميزة التنافسية في جامعة حائل كانت بدرجة كبيرة جدًا، وجاء ترتيب المنطلبات اللازمة لإنتاج المعرفة كمدخل لبناء الميزة التنافسية في جامعة حائل وفق المتوسطات الحسابية كالتالي 
(المتطلبات التتظيمية - المنطلبات البشرية -المتطلبات المادية)، ولم يكن هناك فروق ذات دلالة إحصائية بين استجابات عينة الدراسة حول مدى أهمية المتطلبات اللازمة لإنتاج المعرفة لبناء الميزة التتافسية في تلك المحاور تعود لمتغيرات الدراسة.

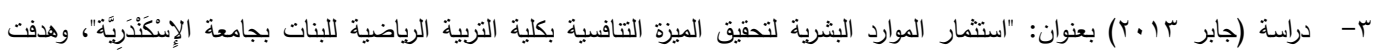
الدراسة إلى التعرف على دَور استثمار الموارد البشرية في تحقيق الميزة التنافسية بكلية التربية الرياضية للبنات بجامعة الإسكندرية، والتعرف على مدى اهتمام إدارة الكلية باستثمار الموارد البشرية، وتوافر متطلبات رأس المال الفكري لتحقيق الميزة التنافسية، واستخدمت الدراسة المنهج الوصفي وأداة الاستبانة مع عينة الدراسة التي بلغت 0؛ مديرًا وإداريًا، وأوصت الدراسة -بناء على نتائجها- بأهية إنشاء صندوق لتنمية الموارد البشرية تابع لكل جامعة مصرية، وضرورة اهتمام وزارة التعليم العالي بإدارة واستثمار رأس المال الفكري، والحفاظ عليه، وتطويره على اعتبار أنه مكون استراتيجي يمنح الجامعات والكليات الميزة التنافسية.

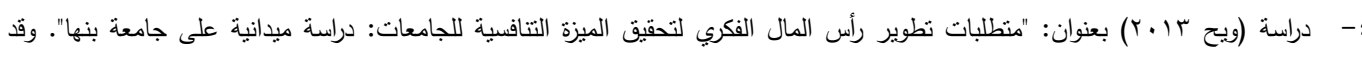
هدفت الدراسة إلى تقديم مقترحات لتقعيل ذَور رأس المال الفكري لتحقيق الميزة التنافسية بجامعة بنها من خلال توضيح الأسس الفكرية لرأس المال الفكري، والميزة التتافسية، ومعرفة العلاقة بينهما، واستخدت الدراسة المنهج الوصفي وأداة الاستبانة والتي وُزعت على 9 ـ1 من أعضاء هيئة التدريس في الجامعة، وأظهرت الدراسة أن امتلاك جامعة بنها لرأس المال الفكري بسهم في تحقيق الميزة التنافسية لها كانت بدرجة متوسطة، ويوجد تفاوت في مكونات رأس المال الفكري في تحقيق الميزة التنافسية لجامعة بنها، وأن رأس المال التنظيمي هو المجال الأقل تأثيرًا

في تحقيق الميزة التنافسية بجامعة بنها، في حين أن رأس المال المعلوماتي هو المجال الأكثر تأثيرًا في تحقيق الميزة التنافسية بجامعة بنها.

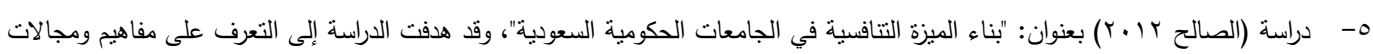
واستراتيجيات بناء الميزة التنافسية في الجامعات الحكومية وأهم المنطلبات لكل من المجالات والاستراتيجيات، واستخدمت الدراسة المنهج الوصفي المسحي وأداة الاستبانة التي طُبقَتْت على أعضاء مجالس ست جامعات هي (أم القرى، الملك سعود، الإمام محمد بن سعود، الملك عبد العزيز ، الملك فهد، الملك فيصل)، وبلغ عددهم ب † أعضاء، وأظهرت الدراسة أن أعضاء مجالس الجامعات يدركون مفهوم الميزة التنافسية بصورة مرتفعة جدًا أن مجالات البحث العلمي والتعليم والتقنية وإنتاج المعرفة هي المجالات الأكثر أهمية لبناء الميزة التنافسية في الجامعات السعودية ، كما تُعتبر استراتيجيات التمايز والمقارنة المرجعية والتحالفات الاستراتيجية هي الخيارات الأنسب استراتيجيًا لبناء الميزة التنافسية في الجامعات الحكومية السعودية، وأوصت الدراسة في ختامها بضرورة استثمار ارتفاع إدراك أعضاء مجالس الجامعات الحكومية السعودية لمفهوم الميزة التنافسية عبر العمل على تطبيق إدارة التميز في الجامعات. 4- دراسة (Essary 2011) بعنوان: "استكثاف نطوير نموذج الميزة التنافسية للتعليم عبر الإنترنت في جامعة أثينا بولاية الباما"، وهدفت الدراسة إلى وضع نموذج لميزة نتافسية للتعلم عبر الإنترنت في جامعة أثينا، واستخدم الباحث المنهج الوصفي وأداة الاستبانة، وأظهرت الدراسة قلة وجود أدوات التخطيط التعليمي وصنع القرار في الجامعة، وأن النموذج المعتمد على الميزة التتافسية يساعد في التخطيط المستقبلي للجامعات، وتوصلت الدراسة في نهايتها إلى وضع نموذج للميزة التتافسية من خلال تحليل نقاط القوة، ومواطن الضعف، والفرص المتاحة، والتهديدات 


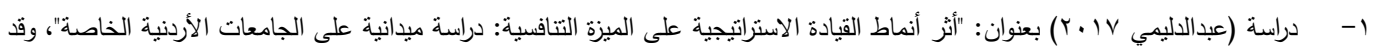
هدفت الدراسة إلى التعرف على أثر أنماط القيادة الاستراتيجية على الميزة التتافسية في الجامعات الخاصة، حيث تتاولت الدراسة ثلاثة أبعاد للقيادة الاستراتيجية (هي القيادة التبادلية، والقيادة التحويلية، والقيادة الريادية) وبعدين للميزة التتافسية (هما التمايز ، والتكلفة)، وتكوَّن مجتمع الدراسة من الجامعات الأردنية الخاصة في عَمَّان وعددها سبع جامعات، ونم توزيع أداة الدراسة الاستبيان على rVY عضوًا في

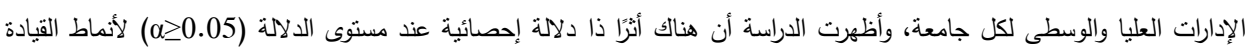
الاستراتيجية على الميزة التتافسية من وجهة نظر الإدارة العليا والؤسطى في الجامعات الأردنية الخاصة. دراسة (خليل V V . Y) بعنوان: "القيادة الاستراتيجية، ودورها في تحسين الميزة التنافسية في الجامعات المصرية"، وهدفت الدراسة إلى إلقاء الضوء على الأطر النظرية والفكرية للقيادة الاستراتيجية، والميزة التنافسية بالأدبيات الإدارية المعاصرة، ورصد واقع القيادة الاستراتيجية والميزة التتافسية بالجامعات المصرية من وجهة نظر أعضاء هيئة التدريس فيها، وتقديم مقترحات لتطبيق القيادة الاستراتيجية لتحسين الميزة التتافسية في الجامعات المصرية. وقد أظهرت الدراسة أنَّ أبعادَ القيادة الاستراتيجية تمارس بدرجة متوسطة، كما أن أبعاد الميزة التتافسية منوفرة بدرجة متوسطة أيضًا، كما أظهرت الدراسة أن هناك علاقة ارتباطية بين متغيرَي الدراسة (القيادة الاستراتيجية، والميزة

\section{النتافسية) قوية وموجهة.}

\section{التعليق على الدراسات السيابقة:}

من خلال تتبع الدراسات السابقة ذات الصلة بمتغيري الدراسة (القيادة الاستراتيجية، والميزة التتافسية) تبين أن الدراسات التي درست العلاقة بينهما في مؤسسات التعليم العالي محدودة جذًا، وحيث إن منهجية الدراسة الحالية اعتمدت على الدراسات التي أجريت على متغيري الدراسة في مؤسسات التعليم العالي فإنها قد استفادت من هذه الدراسات في بناء الإطار النظري للدراسة الحالية.

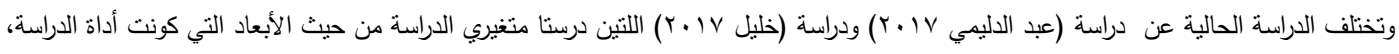
حيث درست دراسة (عبد الدليمي Vا • r) ثلاثة أبعاد للقيادة الاستراتيجية (هي القيادة التبادلية، والقيادة التحويلية، والقيادة الريادية) وبُعدين للميزة التتافسية (هما التمايز، والتكلفة)، في حين درست دراسة (خليل V V r خمسة أبعاد للقيادة الاستراتيجية (هي: التحويلي، والإداري، والسياسي، والأخلاقي، والثقافي) وخمسة أبعاد للميزة التتافية (هي: الجودة، والتكلفة، والمرونة، والتسليم، والإبداع)، أما الدراسة الحالية فتدرس أربعة أبعاد للقيادة الاستراتيجية (هي: التوجه الاستراتيجي، وسمات امتلاك رأس المال البشري، والثقافة التنظيمية، وتطبيق نظام رقابي منوازن)، وأربعة أبعاد للميزة التتافسية (هي: موارد الجامعة وقدراتها، والجودة والابتكار ، والتعلم التنظيمي والتحسين المستمر ، والتكيف والاستدامة).

\section{منهيجية الدراسة وإجيراء|تها}

\section{منهج الدراسة:}

استخدمت الدراسة المنهج الوصفي والذي يعتمد على الواقع وتفسيره، ولا يقتصر على جمع البيانات وتبويبها، وقد هدفت الدراسة الحالية إلى التعرف على درجة ممارسة القيادة الاستراتيجية في جامعة الطائف، وكذلك التعرف على درجة تحقيق الميزة التتافسية بجامعة الطائف، والتعرف على العلاقة الارتباطية

\section{مجتمع الدراسة:}


تكون مجتمع الدراسة من جميع أعضاء هيئة التدريس بجامعة الطائف الحاصلين على درجة الدكتوراه بدرجاتهم الثثلاث (أستاذ- أستاذ مشارك- أستاذ مساعد)، ومن الجنسين (ذكور - إناث) والذين بلغ عددهم حسب ما جاء في العدد (•؛) من إحصائيات التعليم للعام VI • rم: (ع • I ( أعضاء، والجدول التالي يوضع مميزات مجتمع الدراسة.

\begin{tabular}{|c|c|c|c|c|}
\hline النسبة & المجموع & العدد & الجنس & الدرجة العلمبة \\
\hline \multirow{2}{*}{$13.65 \%$} & \multirow{2}{*}{219} & 190 & ذكر & \multirow{2}{*}{ أستاذ } \\
\hline & & 29 & أنثى & \\
\hline \multirow{2}{*}{$24.44 \%$} & \multirow{2}{*}{392} & 317 & ذكر & \multirow{2}{*}{ أستاذ مشارك } \\
\hline & & 75 & أنثى & \\
\hline \multirow{2}{*}{$61.91 \%$} & \multirow{2}{*}{993} & 640 & ل ذكر & \multirow{2}{*}{ أستاذ مساعد } \\
\hline & & 353 & أنثى & \\
\hline $71.51 \%$ & \multicolumn{2}{|c|}{1147} & ذكر & \multirow{2}{*}{ المجموع } \\
\hline $28.49 \%$ & \multicolumn{2}{|c|}{457} & أنثى & \\
\hline $100 \%$ & \multicolumn{2}{|c|}{1604} & \multicolumn{2}{|c|}{ المجموع الكلي } \\
\hline
\end{tabular}

\section{عينة الدراسة:}

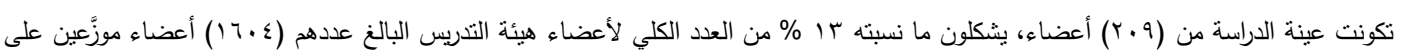
متغيري الدراسة (الجنس - الدرجة العلمية) على النحو التالي: -

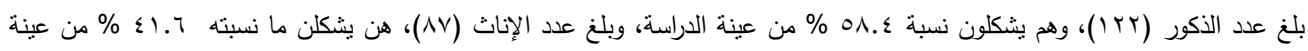

$$
\text { - }
$$

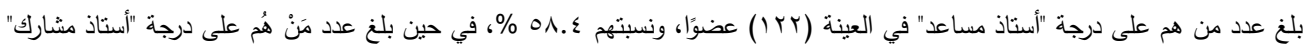

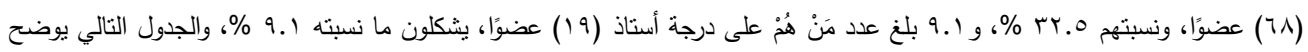

ذلك التوزيع:

\begin{tabular}{|c|c|c|c|}
\hline النسبة المئوية & العدد & \multicolumn{2}{|c|}{ التصنيف } \\
\hline 58.4 & 122 & ذكر & \multirow{3}{*}{ الجنس } \\
\hline 41.6 & 87 & أنثى & \\
\hline 100.0 & 209 & كلي & \\
\hline 9.1 & 19 & أستاذ & الدرجة \\
\hline
\end{tabular}

جدول (r) توزيع عينة الدراسة حسب متغيري (الجنس، والدرجة الأكاديمية) 


\begin{tabular}{|c|c|c|c|}
\hline 32.5 & 68 & أستاذ مشارك & \multirow[t]{3}{*}{ الأكاديمية } \\
\hline 58.4 & 122 & أستاذ مساعد & \\
\hline 100.0 & 209 & كلي & \\
\hline
\end{tabular}

\section{الصدق والثيات:}

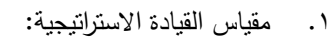

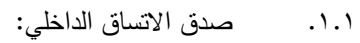

تم حساب صدق الاتساق الداخلي من خال حساب معامل ارتباط بيرسون بين فقرات كل محور والدرجة الكلية لذلك الححور ، وكانت الننائج كما هو

موضح في الجدول رقم (r)، حيث تشير إلى وجود اتساق داخلي بين الفقرات، وكذلك الصدق البنائي من خلا حساب معامل ارتباط بيرسون بين كل محور

والدرجة الكلية للمقياس كما هو موضح في الجدول رقم (؟).

الجدول (ץّ) معامل ارتباط بيرسون بين فقرات كل محور والدرجة الكلية لذلك الدحور

\begin{tabular}{|c|c|c|c|c|c|c|c|}
\hline معامل ارتباط بيرسون & الفقرة & معامل ارتباط بيرسون & الفقرة & معامل ارتباط بيرسون & الفقرة & معامل ارتباط بيرسون & الفقرة \\
\hline \multicolumn{2}{|c|}{ تطبيق نظام رقابي متوازن } & \multicolumn{2}{|c|}{ الثقافة التنظيمية } & \multicolumn{2}{|c|}{ سمات امتلاك رأس المال البشري } & \multicolumn{2}{|c|}{ التوجه الاستراتيجي } \\
\hline $.908^{* * *}$ & 1 & $.946 * *$ & 1 & $.844 * *$ & 1 & $.652 * *$ & 1 \\
\hline $.808^{* *}$ & 2 & $.910 * *$ & 2 & $.856^{* * *}$ & 2 & $.918 * *$ & 2 \\
\hline $.873 * *$ & 3 & $.905^{* *}$ & 3 & $.872 * *$ & 3 & $.800^{* * *}$ & 3 \\
\hline $.907 * *$ & 4 & $.940 * * *$ & 4 & $.898 * *$ & 4 & $.862 * *$ & 4 \\
\hline $.975^{* * *}$ & 。 & $.893^{* * *}$ & 。 & $.734 * *$ & 。 & $.527 * *$ & 。 \\
\hline $.926^{* * *}$ & 1 & $.865^{* *}$ & 1 & $.850 * *$ & 1 & $.879 * *$ & 7 \\
\hline
\end{tabular}

\% الارتباط ذو دلالة إحصائية عند مستوى دلالة

الجدول رقم (§) نتائج معامل الارتباط بيرسون بين كل محور والمقياس ككل.

\begin{tabular}{|c|c|}
\hline معامل الارتباط & 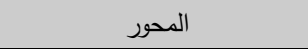 \\
\hline $.939 * *$ & التوجه الاستراتيجي \\
\hline $.981 * *$ & سمات امتلاك رأس المال البشري \\
\hline $.959 * *$ & الثقافة التتظيمية \\
\hline $.902 * *$ & تطبيق نظام رقابي منوازن \\
\hline
\end{tabular}

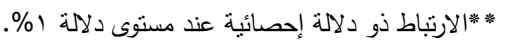


من خلال الجدولين (r، ؟) يتضح أن هناك علاقة ارتباطية بين كل عبارة من عبارات (الجزء الأول من الاستبيان) المتعلق بقياس درجة ممارسة القيادة الاستراتيجية والدرجة الكلية للبعد الذي تنتمي إليه في كل محور من محاور الاستبانة، مما يدل على الاتساق الداخلي بين هذه العبارات والدرجة الكلية للبعد، مما يؤكد صدق الاستبانة، وصلاحيتها للنطبيق وقياس ما وضعت لقياسه.

(r.

تم التحقق من ثبات الأداة من أسلوب معامل ألفا كرونباخ حيث تم حساب الثبات لكل محور من محاور المقياس، وكذلك على المستوى الكلي، وقد تبين من

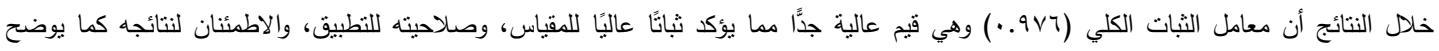

(0) (0) (0)

جدول (0) معامل ثبات ألفا كرونباخ لمحاور الدراسة

\begin{tabular}{|c|c|c|}
\hline معامل ألفا كرونباخ & عدد العبارات & المحاور \\
\hline 0.863 & 7 & التوجه الاستراتيجي \\
\hline 0.913 & 7 & سمات امتلاك رأس المال البشري \\
\hline 0.957 & 7 & الثقافة التتظيمية \\
\hline 0.953 & 1 & تطبيق نظام رقابي متوانن \\
\hline 0.976 & $r \varepsilon$ & مقياس القيادة الاستراتيجية \\
\hline
\end{tabular}

r. مقياس الميزة التتافسية:

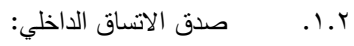

تم حساب صدق الاتساق الداخلي من خلا حساب معامل ارتباط بيرسون بين فقرات كل محور والدرجة الكلية لذلك المحور، وكانت النتائج كما هو موضح في الجدول رقم (؟) حيث تثشير إلى وجود اتساق داخلي بين الفقرات، وكذلك الصدق البنائي من خلال حساب معامل ارتباط بيرسون بين كل محور والدرجة الكلية للمقياس وكما هو موضح في الجدول رقم (؟).

الجدول († ) معامل ارتباط بيرسون بين فقرات كل محور والدرجة الكلية لذلك المحور

\begin{tabular}{|c|c|c|c|c|c|c|c|}
\hline | معامل ارتباط بيرسون & 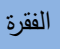 & معامل ارتباط بيرسون & الفقرة & معامل ارتباط بيرسون & الفقرة & معامل ارتباط بيرسون & الفقرة \\
\hline \multicolumn{2}{|c|}{ التكيف والاستدامة } & \multicolumn{2}{|c|}{ التعلم التنظيمي والتحسين المستمر } & \multicolumn{2}{|c|}{ الجودة والابتكار } & \multicolumn{2}{|c|}{ موارد الجامعة وقدراتها } \\
\hline $.981 * *$ & 1 & $.985^{* * *}$ & 1 & $.969^{* * *}$ & 1 & $.950 * *$ & 1 \\
\hline $.955^{* * *}$ & 2 & $.952 * *$ & 2 & $.948 * *$ & 2 & $.933^{* *}$ & 2 \\
\hline
\end{tabular}




\begin{tabular}{|c|c|c|c|c|c|c|c|}
\hline $.955^{* * *}$ & 3 & $.957^{* * * *}$ & 3 & $.982^{* * *}$ & 3 & $.962^{* * *}$ & 3 \\
\hline .954 ** & 4 & .881 * * & 4 & $.942^{* * * *}$ & 4 & .930 * * & 4 \\
\hline .936 ** & 0 & $.948^{* * *}$ & 。 & $.976^{* * *}$ & 0 & $.947 * *$ & 。 \\
\hline .960 *** & 7 & $.950^{* * *}$ & 7 & $.950^{\text {*** }}$ & 7 & $.948^{* * *}$ & 7 \\
\hline
\end{tabular}

\% الارتباط ذو دلالة إحصائية عند مستوى دلالة

\begin{tabular}{|c|c|}
\hline معامل الارتباط & المحور \\
\hline $.984 * *$ & موارد الجامعة وقدراتها \\
\hline $.980 * *$ & الجودة والابتكار \\
\hline $.963 * *$ & التعلم التظظيمي والتحسين المستمر \\
\hline $.978 * *$ & التكيف والاستدامة \\
\hline
\end{tabular}

\% الارتباط ذو دلالة إحصائية عند مستوى دلالة

من خلد الجدولين (T، V) يتضح أن هناك علاقة ارتباطية بين كل عبارة من عبارات (الجزء الثاني من الاستيان) المتعلق بقياس درجة تحقق الميزة التتافية، والدرجة الكلية للبعد الذي تتنمي إليه في كل محور من محاور الاستبانة، مما يدل على الاتساق الداخلي بين هذه العبارات والدرجة الكلية للبعد، مما يؤكد صدق الاستبانة، وصلاحيتها للتطبيق وقياس ما وُضعت لقياسه.

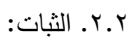
تم التحقق من ثبات الأداة من أسلوب معامل ألفا كرونباخ حيث تم حساب الثبات لكل محور من محاور المقياس، وكذلك على المستوى الكلي، وقد تبين من خلال النتائج أن معامل الثبات الكلي (ب99. ·)، وهي قيم عالية جدًا مما يؤكد ثباتًا عاليا للمقياس، وصلاحيته للنطبيق، والاطمئنان لنتائجه، كما يوضح

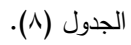
جدول (^) معامل ثبات ألفا كرونباخ لمحاور الدراسة

\begin{tabular}{|c|c|c|}
\hline معامل ألفا كرونباخ & عدد العبارات & المحاور \\
\hline 0.975 & 7 & موارد الجامعة وقدراتها \\
\hline 0.983 & 7 & الجودة والابتكار \\
\hline 0.975 & 7 & التعلم التتظيمي والتحسين المستمر \\
\hline 0.981 & 7 & التكيف والاستدامة \\
\hline 0.993 & $r \varepsilon$ & مقياس الميزة التنافسية \\
\hline
\end{tabular}




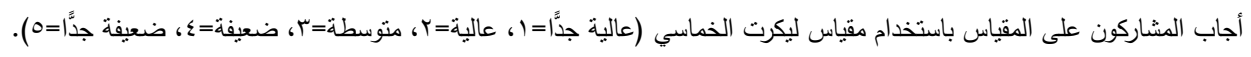

المعيار الإحصائي:

للحكم على مستوى ممارسة القيادة الاستراتيجية ودرجة تحقق الميزة التتافسية اعتمد الباحث على تصنيف المتوسطات الحسابية كالآتي:

\begin{tabular}{|c|c|c|c|c|c|}
\hline ضعيفة جدًا & ضعيفة ل & متوسطة & عالية & عالية جدًا & مستوى الممارسة أو التحقق \\
\hline أقل من •^.1. & r.T. -1.11 & r.乏. - - . . & 纟.r. -r.s) & $0-\varepsilon . r)$ & المتوسط الحسابي \\
\hline
\end{tabular}

\section{الإجابة على أسئلة الدراسة:}

السؤال الأول:

"ما درجة ممارسة القيادة الاستراتيجية بجامعة الطائف من وجهة نظر أعضاء هيئة التكريس؟"

تم قياس وجهات نظر أعضاء هيئة التدريس باستخدام الدرجات المأخوذة من مقياس القيادة الاستراتيجية، حيث يشنمل المقياس على خمس درجات هي إجمالي مقياس القيادة الاستراتيجية (التوجه الاستراتيجي، وسمات امتلاك رأس المال البشري، والثقافة التنظيمية، وتطبيق نظام رقابي منوازن)، وتم استخدام التحليل الوصفي من خلا المتوسطات الحسابي والانحرافات المعيارية لدرجات مقياس القيادة الاستراتيجية وتفرعاته للإجابة هذا السؤال. وكما هو موضح في الجدول رقم (9) فإن المتوسط الكلي لمقياس القيادة الاستراتيجية (SD = 0.81 ، M = 3.25) يشير إلى مستوى ممارسة منوسطة مما يدل على أن لدى القيادات الأكاديمية درجة ممارسة منوسطة للقيادة الاستراتيجية. - - وعلى مستوى ممارسة القيادات الأكاديمية لسمات امتلاك رأس المال البشري كان منوسط الدرجات (MD=3.29، M=0.80) يشير إلى مستوى

$$
\text { متوسط أيضًا. }
$$

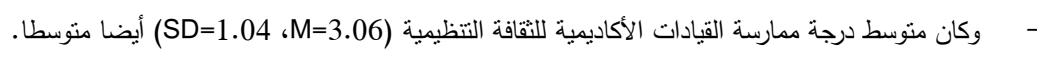

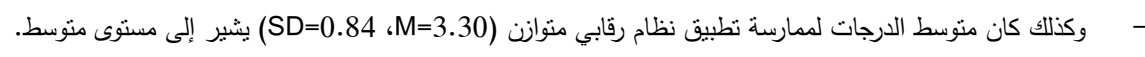
الجدول (9) المتوسطات الحسابي والانحرافات المعيارية لارجة ممارسة أعضاء الهيئة التدريسية للقيادة الاستراتيجية

\begin{tabular}{|c|c|c|c|}
\hline درجة الممارسة & SD & M & 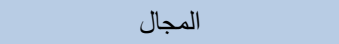 \\
\hline متوسطة & 0.75 & 3.36 & التوجه الاستراتيجي \\
\hline متوسطة & 0.80 & 3.29 & سمات امتلاك رأس المال البشري \\
\hline متوسطة & 1.04 & 3.06 & الثقافة التنظيمية \\
\hline متوسطة & 0.84 & 3.30 & تطبيق نظام رقابي منوازن \\
\hline متوسطة & 0.81 & 3.25 & مقياس ممارسات القيادة الاستراتيجية \\
\hline
\end{tabular}

M : المتوسط الحسابي، SD: الانحراف المعياري

بنقسم هذا السؤال إلى أربع أسئلة فرعية حول (التوجه الاستراتيجي، وسمات امتلاك رأس المال البشري، والثقافة التنظيمية، تطبيق نظام رقابي منوازن). 
وللإجابة على هذا السؤال تم استخدام التحليل الإحصائي الوصفي من خلال المنوسطات والاتحرافات المعيارية. - - - التوجه الاستراتيجي:

تم ترتيب منوسط درجة ممارسة التوجه الاستراتيجي من قبل أعضاء هيئة التدريس من الأكثر ممارسة إلى الأقل ممارسة كما هو موضح في الجدول (• ()، حيث كان أكثر فقرة ممارسة هو (تنبي رؤية الجامعة الاستراتيجية) (M=3.78) يثير إلى مستوى ممارسة عالية لهذه الفقرة. أما الفقرة الثانية وهي (القدرة على الاستفادة من التجارب الناجحة للجامعات المحلية والعالمية) (M=3.66) يشير إلى مستوى ممارسة عالية لهذه الفقرة. والفقرة الثالثة وهي (بناء خطط واضحة لتقعيل رسالة الجامعة) (M=3.46) يشير إلى مستوى ممارسة عالية لهذه الفقرة. الأمر الرابع كان (التصور الواضح عن البيئة الخارجية للجامعة وتحدياتها) (M=3.26) يثير إلى مستوى ممارسة متوسطة لهذه الفقرة. وكانت الفقرة الخامسة (دراسة البيئة الداخلية للجامعة (نقاط القوة - نقاط الضعف) ئ3.07) ورسالتها) (M=2.91) تشير إلى مستوى ممارسة منوسطة لهذه الفقرة. الجدول (• () المتوسطات الحسابي والانحرافات المعيارية لدرجة ممارسة أعضاء الهيئة التدريسية للتوجه الاستراتيجي

\begin{tabular}{|c|c|c|c|c|c|}
\hline 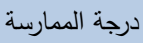 & الترتيب & SD & M & الفقرة & \\
\hline عالية & 1 & 0.96 & 3.78 & تنبي روئية الجامعة الاستراتيجية & 1 \\
\hline عالية & 3 & 0.91 & 3.46 & بناء خطط واضحة لتفعيل رسالة الجامعة & 2 \\
\hline 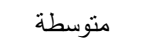 & 5 & 0.93 & 3.07 & دراسة البيئة الداخلية للجامعة (نقاط القوة - نقاط الضعف) & 3 \\
\hline منوسطة & 4 & 0.90 & 3.26 & التصور الواضح عن البيئة الخارجية للجامعة وتحدياتها & 4 \\
\hline عالية & 2 & 0.97 & 3.66 & القدرة على الاستفادة من التجارب الناجحة للجامعات الهحلية والعالمية & 5 \\
\hline متوسطة & 6 & 1.12 & 2.91 & مشاركة العاملين في الجامعة في إعداد خطط تفعيل رؤية الجامعة ورسالتها & 6 \\
\hline
\end{tabular}

M M M المتوسط الحسابي، SD: الانحراف المعياري.

- سمات امتلاك رأس المال البشري

تم ترتيب متوسط درجة ممارسة سمات امتلاك رأس المال البشري من قبل أعضاء هيئة التدريس من الأكثر ممارسة إلى الأقل ممارسة كما هو موضح في الجدول (' ()، حيث كان أكثر فقرة ممارسة هو (تسجيل الإنتاج الفكري للعاملين في الجامعة لحمايته والحصول على براءات الاختراع والتميز البحثي) يشير إلى مستوى ممارسة عالية لهذه الفقرة، أما الفقرة الثانية فهي أن (الإيمان بأهمية التدريب في تطوير العمل) (M=3.41) يشير إلى مستوى ممارسة عالية لهذه الفقرة. والفقرة الثالثة هي (عقد شراكات مع مؤسسات الهتمع المحلي المتميزة لدعم وتحسين بيئة البحث العلمي) (M=3.33) يشير إلى مستوى ممارسة متوسط لهذه الفقرة. الأمر الرابع كان (توفير الإمكانيات المادية المناسبة لتطوير العمل) (M=3.20) يشير إلى مستوى ممارسة متوسطة لهذه الفقرة. وكانت الفقرة الخامسة (المساهمة في رفع الحالة المعنوية للعاملين) (M=3.17) يشير إلى مستوى ممارسة متوسطة لهذه الفقرة. وكانت الفقرة السادسة (العمل على استقطاب واختبار الكفاءات المميزة والقادرة على الإبداع والابتكار ) (M=3.05) يشير إلى مستوى ممارسة متوسطة لهذه الفقرة. الجدول (1) المتوسطات الحسابي والانحرافات المعيارية لدرجة ممارسة أعضاء الهيئة التدريسية لسمات امتلاك رأس المال البشري

\begin{tabular}{|c|c|c|c|c|c|}
\hline الترتيب| & SD & M & \multicolumn{2}{|c|}{} \\
\hline
\end{tabular}




\begin{tabular}{|c|c|c|c|c|c|}
\hline 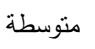 & $\varepsilon$ & 0.85 & 3.20 & توفير الإمكانيات المادية المناسبة لنطوير العمل & 2 \\
\hline 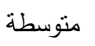 & 1 & 1.14 & 3.05 & العمل على استقطاب واختيار الكفاءات المميزة والقادرة على الإبداع والابتكار & 3 \\
\hline 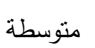 & r & 0.94 & 3.33 & عقد شراكات مع مؤسسات المجتمع المحلي المتميزة لدعم وتحسين بيئة البحث العلمي & 4 \\
\hline 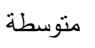 & $\circ$ & 0.95 & 3.17 & المساهمة في رفع الحالة المعنوية للعاملين & 5 \\
\hline عالية & 1 & 1.10 & 3.58 & تسجيل الإنتاج الفكري للعاملين في الجامعة لحمايته والحصول على براءات الاختراع والتميز البحثي & 6 \\
\hline
\end{tabular}

M

- - - الثقافة التظيمية:

تم ترتيب متوسط درجة ممارسة الثقافة التظظيمية من قبل أعضاء هيئة التدريس من الأكثر ممارسة إلى الأقل ممارسة كما هو موضح في الجدول (Y))، حيث كان أكثر فقرة ممارسة هو (ربط العمل بالقيم الأخلاقية (النزاهة والثفافية)) (M=3.40) يثير إلى مستوى ممارسة متوسط لهذه الفقرة. أما الفقرة الثانية فهي أن (تفويض الصلاحيات في المستويات الإدارية المختلفة) (M=3.15) يشير إلى مستوى ممارسة منوسط لهذه الفقرة. والفقرة الثالثة هي (تثجيع بناء فرق العمل بالجامعة) (M=3.09) يشير إلى مستوى ممارسة متوسط لهذه الفقرة. الأمر الرابع كان (غرس الأفكار التي تعزز قيم العمل) (M=3.01) يشير إلى مستوى ممارسة متوسطة لهذه الفقرة. وكانت الفقرة الخامسة (المساهمة في تفعيل اللامركزية وتمكين الأفراد في صناعة القرار) (M=2.87) يشير إلى مستوى ممارسة منوسطة لهذه الفقرة. وكانت الفقرة السادسة (المساواة بين الأفراد لتقليل مستويات الصراع التنظيمي) (M=2.85) يشير إلى مستوى ممارسة منوسطة لهذه الفقرة. الجدول (T) المتوسطات الحسابي والاتحرافات المعيارية لدرجة ممارسة أعضاء الهيئة التريسية للثقافة التنظيمية

\begin{tabular}{|c|c|c|c|c|c|}
\hline درجة الممارسة & الترتيب & SD & M & الفقرة & \\
\hline متوسطة & 1 & 1.17 & 3.40 & ربط العمل بالقيم الأخلاقية (النزاهة والثفافية) & 1 \\
\hline متوسطة & 1 & 1.24 & 2.85 & المساواة بين الأفراد لتقليل مستويات الصراع التتظيمي & 2 \\
\hline متوسطة & $\varepsilon$ & 1.20 & 3.01 & غرس الأفكار التي تعزز قيم العمل & 3 \\
\hline 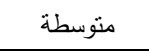 & $\circ$ & 1.17 & 2.87 & المساهمة في تفعيل اللامركزية وتهكين الأفراد في صناعة القرار & 4 \\
\hline متوسطة & r & 0.92 & 3.09 & تشجيع بناء فرق العمل بالجامعة & 5 \\
\hline منوسطة & r & 1.13 & 3.15 & تفويض الصلاحيات في المستويات الإدارية المختلفة & 6 \\
\hline
\end{tabular}

M

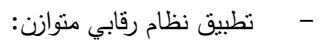

تم ترتيب منوسط درجة ممارسة نطبيق نظام رقابي متوازن من قبل أعضاء هيئة التدريس من الأكثر ممارسة إلى الأقل ممارسة كما هو موضح في الجدول (T) (1)، حيث كان أكثر فقرة ممارسة هو (العمل على تطوير خدمات الجامعة بما يعزز سمعة الجامعة) (M=3.44) يشير إلى مستوى ممارسة عالية لهذه الفقرة. أما الفقرة الثانية فهي أن (وضع إجراءات واليات عمل نتابع وتراقب الأنشطة المنفذة وتقارنها بالمخططة) (M=3.41) يشير إلى مستوى ممارسة عالية لهذه الفقرة. والفقرة الثالثة هي (تفعيل الرقابة لتكون من أهم وظائف القادة الاستراتيجيين في الجامعة) (M=3.41) يشير إلى مستوى ممارسة عالية لهذه الفقرة. الأمر الرابع كان (الاستفادة من أداء الجامعات المنافسة لتحسين مستوى خدماتها المقدة) (M=3.30) يثير إلى مستوى ممارسة متوسطة لهذه الفقرة. 
وكانت الفقرة الخامسة (الحرص على الاستفادة من التغذية الراجعة من الأداء الرقابي لتحسين عمليات الجامعة الأساسية) (M=3.16) بشير إلى مستوى ممارسة متوسطة لهذه الفقرة. وكانت الفقرة السادة (الاهتمام بالتغذية الراجعة بما ينعكس على مجريات العمل داخل الجامعة بشكل ايجابي) (M=3.08) يشير إلى مستوى ممارسة منوسطة لهذه الفقرة.

\begin{tabular}{|c|c|c|c|c|c|}
\hline 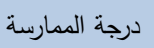 & الترتيب & SD & M & الفقرة & \\
\hline عالية & 3 & 0.87 & 3.41 & تفعيل الرقابة لنكون من أهم وظائف القادة الاستراتيجيين في الجامعة & 1 \\
\hline عالية & 2 & 0.81 & 3.41 & وضع إجراءات واليات عمل تتابع وتراقب الأثشطة المنفذة وتقارنها بالمخططة & 2 \\
\hline متوسطة & 6 & 0.92 & 3.08 & الاهنمام بالتغذية الراجعة بما ينعكس على مجريات العمل داخل الجامعة بشكل ايجابي & 3 \\
\hline 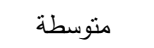 & 4 & 0.95 & 3.30 & الاستفادة من أداء الجامعات المنافسة لتحسين مستوى خدماتها المقدمة & 4 \\
\hline عالية & 1 & 1.01 & 3.44 & العمل على تطوير خدمات الجامعة بما يعزز سمعة الجامعة. & 5 \\
\hline منوسطة & 5 & 1.02 & 3.16 & الحرص على الاستقادة من التغذية الراجعة من الأداء الرقابي لتحسين عمليات الجامعة الأساسية & 6 \\
\hline
\end{tabular}

M : M المتوسط الحسابي، SD: الانحراف المعياري

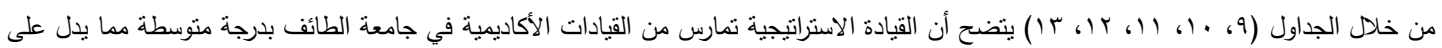
حاجة هذه القيادات لإدراك أهمية ممارسة القيادة الاستراتيجية لتحقيق توجهات الجامعة المستقبلية من خلال توجيه برامج التتمية المهنية لهذه القيادات للاهتمام بهذا الأمر في المستقبل، والعمل على تفعيل التخطيط الاستراتيجي والياته في برامج الجامعة المستقبلية، وتتفت نتائج الدراسة الحالية مع نتائج دراسة خليل(V ا • rم) والثي أظهرت درجة ممارسة القيادات الأكاديمية للقيادة الاستراتيجية في الجامعات المصرية كانت بدرجة متوسطة.

السؤال الثاني:

\section{"ما درجة تحقيق الميزة التتافبية بجامعة الطائف من وجهة نظر أعضاء هيئة التريس؟"}

تم قياس وجهات نظر أعضاء هيئة التدريس باستخدام الدرجات المأخوذة من مقياس الميزة التتافسية حيث يشتمل المقياس على خمس درجات وهي: إجمالي مقياس الميزة التتافية، وهي (موارد الجامعة وقدراتها، والجودة والابتكار، والتعلم التنظيمي والتحسين المستمر، والتكيف والاستدامة)، وتم استخدام التحليل الوصفي من خلال المتوسطات الحسابي والانحرافات المعيارية لدرجات مقياس الميزة التنافسية وتفرعاته للإجابة هذا السؤال كما هو موضح في الجدول رقم (ع ()، فإن المتوسط الكلي لمقياس الميزة التتافسية (MD=0.96، M.20) مما يدل على أن هناك درجة تحقق متوسطة للميزة التتافسية من وجهة نظر أعضاء هيئة التدريس.

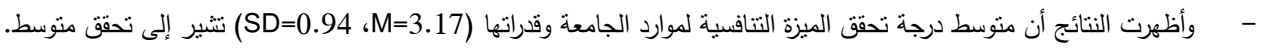
- على مستوى الميزة التنافسية للجودة والابتكار كان متوسط درجات تحققها (SD=0.99، M=3.19، يشير إلى مستوى متوسط.

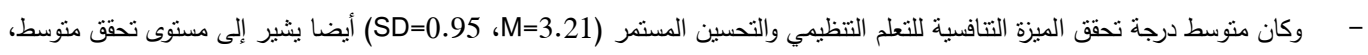




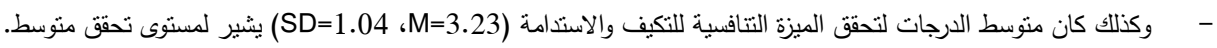

الجدول (ع () المتوسطات الحسابي والانحرافات المعيارية لدرجة ممارسة أعضاء الهيئة التدريسية للميزة التتافسية

\begin{tabular}{|c|c|c|c|}
\hline درجة التحقق & SD & M & المجال \\
\hline متوسطة & 0.94 & 3.17 & موارد الجامعة وقدراتها \\
\hline منوسطة & 0.99 & 3.19 & الجودة والابتكار \\
\hline 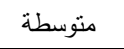 & 0.95 & 3.21 & التعلم التتظيمي والتحسين المستمر \\
\hline 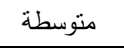 & 1.04 & 3.23 & التكيف والاستدامة \\
\hline متوسطة & 0.96 & 3.20 & مقياس الميزة التتافسية \\
\hline
\end{tabular}

M

ينقسم هذا السؤال إلى أربعة أسئلة فرعية حول (موارد الجامعة وقدراتها، والجودة والابتكار، والتعلم التتظيمي والتحسين المستمر ، والتكيف والاستدامة). وللإجابة على هذا السؤال تم استخدام التحليل الإحصائي الوصفي من خلال المنتسطات والاتحرافات المعيارية.

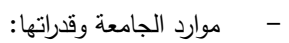

تم ترتيب منوسط درجة تحقق الميزة التففية لموارد الجامعة وقدراتها من وجهة نظر أعضاء هيئة التدريس من الأكثر تحققًا إلى الأقل تحقًًا كما هو موضح في الجدول (ه ()، حيث كان أكثر فقرة تحققًا هي (تهنم الجامعة بمواردها البشرية باعتبارها إحدى أهم القوى الاستراتيجية) (M=3.26) يشير إلى مسنوى تحقق متوسط لهذه الفقرة. أما الفقرة الثانية فهي (تحرص الجامعة على أن تكون مواردها متميزة وذات قيمة) (M=3.26) يشير إلى مستوى تحقق منتسط لهذه الفقرة. والفقرة الثالثة هي (تحدد الجامعة مواردها وفقا لأهميتها الاستراتيجية) (M=3.25) يشير إلى مستوى تحقق متوسط لهذه الفقرة. الفقرة الرابعة كانت (تهنم الجامعة برأس المال الفكري للعاملين فيها كأحد أهم مواردها الاستراتيجية) (M=3.30) يشير إلى مستوى تحقق متوسط لهذه الفقرة. وكانت الفقرة الخامسة (تمتلك الجامعة موارد لا تتوفر لمنافيهها) (M=3.06) يشير إلى مستوى تحقق منوسط لهذه الفقرة. وكانت الفقرة السادسة (تتذذ الجامعة كل الإجراءات الكفيلة بالحفاظ على رأس المال الفكري فيها كمصدر استراتيجي لقونها التنافية ايجابي) (M=3.01) يشير إلى مسنوى تحقق منوسط لهذه الفقرة.

\begin{tabular}{|c|c|c|c|c|c|}
\hline درجة التحقق & الترنيب & SD & $M$ & الفقرة & \\
\hline متوسطة & 2 & 0.95 & 3.26 & تحرص الجامعة على أن نكون مواردها متميزة وذات قيمة. & 1 \\
\hline منوسطة & 3 & 0.89 & 3.25 & تحدد الجامعة مواردها وفقا لأهميتها الاستراتيجية. & 2 \\
\hline منوسطة & 5 & 1.14 & 3.06 & تمنللك الجامعة موارد لا تتوفر لمنافسيها. & 3 \\
\hline متوسطة & 1 & 0.89 & 3.26 & تهنم الجامعة بمواردها البشرية باعتبارها إحدى أهم القوى الاستراتيجية & 4 \\
\hline متوسطة & 4 & 1.04 & 3.15 & تهنم الجامعة برأس المال الفكري للعاملين فيها كأحد أهم مواردها الاستراتيجية & 5 \\
\hline منوسطة & 6 & 1.07 & 3.01 & تتخذ الجامعة كل الإجراءات الكفيلة بالحفاظ على رأس المال الفكري فيها كمصدر استراتيجي لقوتها التتافسية. & 6 \\
\hline
\end{tabular}

M 
تم نرتيب متوسط درجة تحقق الميزة التنفسة للجودة والابتكار من وجهة نظر أعضاء هيئة التدريس من الأكثر تحققًا إلى الأقل تحققًا كما هو موضح في الجدول (7 ا )، حيث كان أكثر فقرة تحققًا هي (تسعى الجامعة بشكل جاد لنطبيق أنظمة الاعتماد والجودة العالمية على كل عملياتها) (M=3.31) يشير إلى مستوى تحقق متوسط لهذه الفقرة. أما الفقرة الثانية فهي (تتبنى الجامعة ثقافة الجودة والابتكار من خلال إدراجها في رؤيتها الاستراتيجية) (M=3.22) يشير إلى مستوى تحقق منوسط لهذه الفقرة. والفقرة الثالثة هي (تعطي الجامعة اهتماما كبيرا للأفكار الابتكارية التي يقدمها العاملون فيها) (M=3.20) يشير إلى مستوى تحقق منتوسط لهذه الفقرة. الفقرة الرابعة كانت (تستعين الجامعة بجهات متخصصة لتوفير أوعية الإبداع والابتكار) (M=3.17) يشير إلى مسنوى تحقق متوسط لهذه الفقرة. وكانت الفقرة الخامسة (يتوفر في الجامعة نظام متكامل لضمان الجودة) (M=3.15) يشير إلى مستوى تحقق متوسط لهذه الفقرة. وكانت الفقرة السادسة (تتميز خدمات الجامعة بأنها ذات نوعية منميزة قياسًا بالمنافسين) (M=3.11) يشير إلى مستوى تحقق متوسط لهذه الفقرة. الجدول (7 () المتوسطات الحسابي والانحرافات المعيارية لدرجة تحقق الميزة التنافسية للجودة والابتكار من وجهة نظر أعضاء هيئة التدريس

\begin{tabular}{|c|c|c|c|c|c|}
\hline درجة تحقق & الترتيب & SD & M & 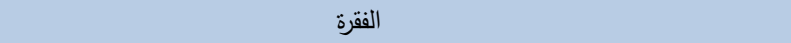 & \\
\hline منوسطة & 2 & 1.03 & 3.22 & تتبنى الجامعة ثقافة الجودة والابتكار من خلا إدراجها في رؤيتها الاستراتيجية. & 1 \\
\hline منوسطة & 6 & 1.02 & 3.11 & تتميز خدمات الجامعة بأنها ذات نوعية متميزة قياسًا بالمنافسين. & 2 \\
\hline منوسطة & 5 & 1.09 & 3.15 & يتوفر في الجامعة نظام متكامل لضمان الجودة. & 3 \\
\hline متوسطة & 1 & 1.01 & 3.31 & تسعى الجامعة بشكل جاد لتطبيق أنظمة الاعتماد والجودة العالمية على كل عملياتها. & 4 \\
\hline 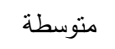 & 3 & 1.10 & 3.20 & تعطي الجامعة اهتماما كبيرا للأفكار الابتكارية التي يقدمها العاملون فيها. & 5 \\
\hline 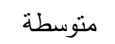 & 4 & 0.92 & 3.17 & تستعين الجامعة بجهات متخصصة لتوفير أوعية الإبداع والابتكار . & 6 \\
\hline
\end{tabular}

M

$$
\text { - - - مالتعلم التظيمي والتحسين المستمر: - }
$$

تم ترتيب منتوسط درجة تحقق الميزة النتافسية للتعلم التتظيمي والتحسين المستمر من وجهة نظر أعضاء هيئة التدريس من الأكثر تحققًا إلى الأقل تحققًا كما هو موضح في الجدول (V) (I)، حيث كانت أكثر فقرة تحققًا هي (تساعد الجامعة العاملين فيها على الحصول على المعلومات التي يحتاجونها بسرعة وسهولة) (M=3.40) يشير إلى مستوى تحقق متوسط لهذه الفقرة. أما الفقرة الثانية وهي (يتوفر لدى الجامعة نظام لحفظ المعلومات واسترجاعها) (M=3.29) فيشير إلى مستوى تحقق متوسط لهذه الفقرة. والفقرة الثالثة وهي (تنظر الجامعة للمشكلات التي نواجها على أنها فرص للتعلم) (M=3.24) فيشير إلى مسنوى تحقق متوسط لهذه الفقرة، والفقرة الرابعة كانت (تتبنى لجامعة مفهوم التعلم التتظيمي بوصفه مصدرا من مصادر المعرفة) (M=3.20) ويشير إلى مستوى تحقق متوسط لهذه الفقرة. وكانت الفقرة الخامسة (تتيح الجامعة للعاملين فيها كل الوسائل والإمكانيات التي تدعم عمليات التعلم) (M=3.06) ويشير إلى مستوى تحقق منوسط لهذه الفقرة، وكانت الفقرة السادة (توفر الجامعة ديناميكيات التعلم التنظيمي لنشجيع المتميزين) (M=3.06) ويشير إلى مستوى تحقق متوسط لهذه الفقرة.

الجدول (V) المتوسطات الحسابي والانحرافات المعيارية لدرجة تحقق الميزة التتافسية للتعلم التنظيمي والتحسين المستمر من وجهة نظر أعضاء هيئة

التدريس

\begin{tabular}{|l|l|l|l|l} 
& الفقرة & SD & M & \\
\hline
\end{tabular}




\begin{tabular}{|c|c|c|c|c|c|}
\hline 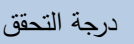 & الترتيب & SD & M & الفقرة & \\
\hline متوسطة & 5 & 1.00 & 3.06 & تتيح الجامعة للعاملين فيها كل الوسائل والإمكانيات التي تدعم عمليات التعلم & 1 \\
\hline متوسطة & 4 & 0.91 & 3.20 & تتبنى الجامعة مفهوم التعلم التتظيمي بوصفه مصدرا من مصادر المعرفة & 2 \\
\hline منوسطة & 6 & 1.14 & 3.06 & توفر الجامعة ديناميكيات التعلم التتظيمي لتشجيع المتميزين & 3 \\
\hline متوسطة & 1 & 1.00 & 3.40 & تساعد الجامعة العاملين فيها على الحصول على المعلومات التي يحتاجونها بسرعة وسهولة & 4 \\
\hline متوسطة & 2 & 0.93 & 3.29 & يتوفر لدى الجامعة نظام لحفظ المعلومات واسترجاعها & 5 \\
\hline متوسطة & 3 & 1.07 & 3.24 & تنظر الجامعة للمشكلات التي تواجهها على أنها فرص للتعلم & 6 \\
\hline
\end{tabular}

M -

تم ترتيب متوسط درجة تحقق الميزة التتافسية للتكيف والاستدامة من وجهة نظر أعضاء هيئة التدريس من الأكثر تحققًا إلى الأقل تحقًًا كما هو موضح في الجدول (1 ( )، حيث كان أكثر فقرة تحققًا هي (تستثر الجامعة قدرات العاملين فيها ومعارفهم لتعزيز مزاياها التتافية) (M=3.44) يشير إلى مستوى تحقق عالٍ لهذه الفقرة. أما الفقرة الثانية فهي (تضع الجامعة الاستدامة النتافسية أحد أهم أهدافها الاستراتيجية) (M=3.35) يشير إلى مسنوى تحقق منوسط لهذه الفقرة. والفقرة الثالثة هي (تجري الجامعة باستمرار تعديلات على برامجها الأكاديمية لتتكيف مع حاجات السوق على المدى البعيد) (M=3.20) يشير إلى مستوى تحقق منوسط لهذه الفقرة. الفقرة الرابعة كانت (لدى الجامعة استراتيجيات واضحة للتكيف مع المتغيرات البيئية المختلفة) (M=3.15) يشير إلى مستوى تحقق متوسط لهذه الفقرة. وكانت الفقرة الخامسة (تستثر الجامعة قدرات العاملين فيها ومعارفهم لتعزيز مزاياها التتافسية) (M=3.15) يثير إلى مستوى تحقق متوسط لهذه الفقرة. وكانت الفقرة السادسة (لدى الجامعة القدرة على تغيير استراتيجياتها للتوافق مع منطلبات الظروف التتافسية) (M=3.06) يشير إلى مستوى تحقق متوسط لهذه الفقرة. الجدول (1) المتوسطات الحسابي والانحرافات المعيارية لدرجة تحقق الميزة التتافية للتكيف والاستدامة من وجهة نظر أعضاء هيئة التدريس

\begin{tabular}{|c|c|c|c|c|c|}
\hline 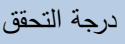 & الترتيب & SD & M & \multicolumn{2}{|l|}{ 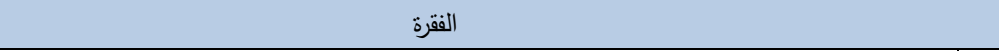 } \\
\hline منوسطة & 4 & 1.04 & 3.15 & لدى الجامعة استراتيجيات واضحة للتكيف مع المتغيرات البيئية المختلفة & 1 \\
\hline منوسطة & 6 & 1.05 & 3.06 & لدى الجامعة القدرة على تغيير استراتيجياتها للتوافق مع منطلبات الظروف التتافسية & 2 \\
\hline 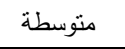 & 3 & 1.01 & 3.20 & تجري الجامعة باستمرار تعديلات على برامجها الأكاديمية لتتكيف مع حاجات السوق على المدى البعيد & 3 \\
\hline 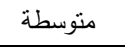 & 5 & 1.09 & 3.15 & تسنتمر الجامعة قدرات العاملين فيها ومعارفهم لتعزيز مزاياها التتافسية & 4 \\
\hline عالية & 1 & 1.18 & 3.44 & تسعى الجامعة للحصول على مراكز تتافسية متقدمة & 5 \\
\hline منوسطة & 2 & 1.17 & 3.35 & تضع الجامعة الاستدامة التتافسية احد أهم أهدافها الاستراتيجية & 6 \\
\hline
\end{tabular}

M

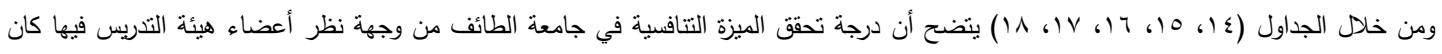
بدرجة منتسطة، مما يدل على أن هناك اهتمامًا متوسطا لدى القيادات الأكاديمية بالميزة التتافية، وقد يعود السبب في ذلك إلى حداثة الجامعة وتوجهها نحو 
بناء ميزات تنافسية جديدة في مجالات جديدة لم يتطرق لها المنافسون، كما أن على القيادة العليا بالجامعة رفع مستوى الوعي لاى القيادات الأكاديمة بأهية

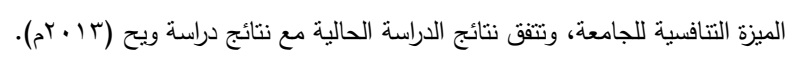

السوال الثأث:

"هل توحد علاقة ارتياطية ذات دلالة إحصائية عند مستوى الدالالة (هج 0.05) بين درجة ممارسة القبادة الاستراتيجية ودرجة تحقيق الميزة التنافسبة

بحامعة الطائف؟"

للإجابة عن السؤال تم استخدام اختبار الارتباط من خلال معامل ارتباط بيرسون كما في الجدول (9 (). الجدول (9 (1) ننائج ارتباط بيرسون بين درجة ممارسة القيادة الاستراتيجية ودرجة تحقق الميزة التنافسية بجامعة الطائف

\begin{tabular}{|c|c|c|c|c|c|c|}
\hline مقياس الميزة التتافسية & والاستدامة & والتعلم التنظيمي & والابتكار & موارد الجامعة & \multicolumn{2}{|c|}{ القيادة الاستراتيجية } \\
\hline $.906^{* *}$ & $.864^{* *}$ & $.869^{* * *}$ & $.923^{* * *}$ & $.884^{* * *}$ & ارنباط بيرسون & \multirow{2}{*}{ التوجه الاستراتيجي } \\
\hline قوي طردي & قوي طردي & قوي طردي & قوي طردي & قوي طردي & الوصف & \\
\hline $.955^{* * *}$ & $.948 * *$ & $.921 * *$ & $.931^{* * *}$ & $.929 * *$ & ارتباط بيرسون & \multirow{2}{*}{ سمات امتلاك رأس المال البشري } \\
\hline قوي طردي & قوي طردي & قوي طردي & قوي طردي & قوي طردي & الوصف & \\
\hline $.898 * *$ & $.866^{* *} *$ & $.823^{* * *}$ & $.906^{* * *}$ & $.911^{* * *}$ & ارنباط بيرسون & \multirow{2}{*}{ الثقافة التنظيمية } \\
\hline قوي طردي & قوي طردي & قوي طردي & قوي طردي & قوي طردي & الوصف & \\
\hline $.789^{* *}$ & $.787 * *$ & $.763^{* * *}$ & $.770^{* * *}$ & $.760 * *$ & ارنباط بيرسون & \multirow{2}{*}{ تطبيق نظام رقابي منوازن } \\
\hline 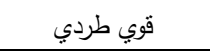 & قوي طردي & قوي طردي & قوي طردي & قوي طردي & الوصف & \\
\hline $.937^{* * *}$ & $.915^{* *}$ & $.890 * *$ & $.933^{* * *}$ & $.922^{* * *}$ & ارنباط بيرسون & \multirow{2}{*}{ مقياس ممارسات القيادة الاستراتيجية } \\
\hline 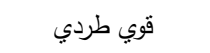 & قوي طردي & 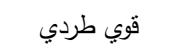 & قوي طردي & 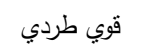 & الوصف & \\
\hline
\end{tabular}

من الجدول (9 ا ) يتضح وجود علاقة طردية قوية ذات دلالة إحصائية بين درجة ممارسة القيادة الاستراتيجية ودرجة تحقق الميزة التتافسية بجامعة الطائف على المستوى الكلي وعلى مستوى الأبعاد كل حدا مثنى مثنى، وهذا يدل على أنه كلما ارتفعت ممارسات القيادة الاستراتيجية لدى القيادات الأكاديمية كلما تحققت الميزة التتافية للجامعة، الأمر الذي يجعل ممارسة أبعاد القيادة الاستراتيجية من قبل القيادات الأكاديمية في جامعة الطائف هو السبيل إلى تحقيق

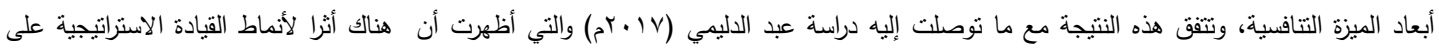
الميزة التتافية في الجامعات الأردنية الخاصة، ودراسة خليل (V ا •rم) والتي أظهرت أن القيادة الاستراتيجية لها في تحسين الميزة التتافية في الجامعات المصرية.

\section{ملخص النتائج:}


ا- أن درجة ممارسة القيادات الأكاديمية بجامعة الطائف للقيادة الاستراتيجية من وجهة نظر أعضاء هيئة التدريس فيها وبأبعادها الأربعة (النوجه الاستراتيجي، وسمات امتالك رأس المال البشري، والثقافة التنظيمية، وتطبيق نظام رقابي منوازن)كانت ممارسة متوسطة. r- أن درجة تحقق الميزة التتافسية بجامعة الطائف من وجهة نظر أعضاء هيئة التنريس فيها وبأبعادها الأربعة (موارد الجامعة وقدراتها، والجودة والابتكار ، والتعلم التنظيمي والتحسين المستمر ، والتكيف والاستدامة) كانت منوسطة. ك- يوجد علاقة طردية قوية ذات دلالة إحصائية بين درجة ممارسة القيادة الاستراتيجية ودرجة تحقق الميزة التنافسية بجامعة الطائف على المستوى الكلي وعلى مستوى الأبعاد كل حدا مشى مثى.

\section{التوصيات والمقترحات:}

$$
\text { بناءً على النتائج السابقة فإن الدراسة توصي بما يلي: }
$$

1- ضرورة تبني إدارة الجامعة لمفهوم القيادة الاستراتيجية عمليا من خلال تفعيل رسالة ورؤية الجامعة وخططها الاستراتيجية على أرض

$$
\text { الواقع، وممارسة أنشطنها وآلياتها لنحقيق أهدافها. }
$$

ץ- ضرورة إدراج مهارات القيادة الاستراتيجية في برامج التتمية المهنية التي تقدمها الجامعة للقيادات الأكاديمية، وربطها بممارساتهم الحقيقية. ب- الاهتمام برأس المال البشري من خلال عمليات (الاستقطاب الفعال، والتنريب الموجه، والثراكات المجتمعية) وذلك لدوره الكبير في تحسين أداء الجامعة وتحقيق ميزة تتافسية لها بين مثيلاتها. ع - ضرورة اهتمام إدارة الجامعة ببناء ثثافة تتظيمية تشجع على الإبداع والابتكار وتدعم عمليات التحسين والتطوير المستمر. ه- ضرورة استفادة الجامعة من تجارب الجامعات العالمية الرائدة والتي تمنلك ميزات تتافسية عالية، ونقلها للجامعة بما يتتاسب مع بيئة

$$
\text { الجامعة وقيمها. }
$$

-ـ ضرورة اهتمام الجامعة بتطوير مواردها (المادية والبشرية)، والمحافظة عليها، وتحسين أدائها بثكل مستمر بما يضمن لها تحقيق

$$
\text { النتافسية مع مثيلاتها. }
$$

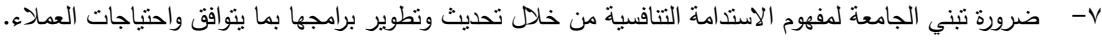
^- إجراء المزيد من الدراسات والبحوث المستقلية حول القيادة الاستراتيجية والميزة التتافسية، وربطهما بمداخل إدارية حديثة يمكن أن تساهم

$$
\text { في تطوير العمل الإداري في الجامعات. }
$$

1- ابن منظور ، محمد بن مكرم (د ت ) لسان العرب ، مؤسسة الالعلمي للمطبوعات ، طا، مج ب ، بيروت ، لبنان. ץ- ابن دريد،محمد بن الحسن(1987)جمهرة اللغة ، دار العلم للماليين كمج) ، بيروت ، لبنان. r- الإبراهيمي، عدنان بدري (2009): درجة فاعلية تقويم أداء أعضاء هيئة التدريس في الجامعات الأردنية لتحقيق الميزة التنافسية لجامعاتهم، مجلة اتحاد الجامعات العربية للتربية وعلم النفس، جامعة دمشق،سورية. 
ع - أبو بكر ، مصطفى محمود (2008): إدارة الموارد البشرية: مدخل تحقيق الميزة التتافية،الدار الجامعية، القاهرة.

ه- أحمد و الفقيه، أشرف السعيد. ومحمد هادي (2011): القيادة الاستراتيجية لرؤساء الأقسام الأكاديمية: دراسة ميدانية بجامعة نجران. مجلة التربية: جامعة الأزهر - كلية التربية.

צ- الأكلبي، عائض شافي (2018):دور القيادة الاستراتيجية في دعم الأداء المؤسسي دراسة علمية بالتطبيق على جامعة شقراء وكلياتها ،مجلة كلية الاقتصاد والعلوم السياسية ،جامعة القاهرة،مصر ،مج19،ع1 V- اد الرب، سيد محمد (2012): القيادة الاستراتيجية، مصر، القاهرة، دار الكتب المصرية. ᄉ- هاشم، رضا محمد حسن (2017): استراتيجيات ومتطلبات تحقيق الميزة التتافسية بجامعة الدمام من وجهة نظر القيادات العليا بالجامعة، مستقبل التربية العربية، مج24، ع106. 9- ويح، محمد عبد الرزاق (2013): منطلبات تطوير رأس المال الفكري لتحقيق الميزة التنافسية للجامعات دراسة ميدانية على جامعة بنها، مجلة كلية التربية،جامعة بنها. • ا- الزهراني، إبراهيم حنش سعيد (2018): القيادة الاستراتيجية وأثرها في تطوير قدرات التعلم التنظيمي: دراسة ميدانية بجامعة أم القرى، المجلة

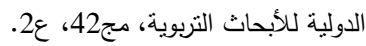
11- الزعبي، حسن علي (2005): نظم المعلومات الاستراتيجية مدخل استراتيجي،عمان، الأردن، دار وائل للنشر . r ا- الحارثي، عبد الله ضيف الله (2018): الهوية الأكاديمية للجامعات السعودية في ضوء الميزة التنافسية: رؤية استشرافية، رسالة دكتوراه غير منشورة، جامعة الملك سعود، المملكة العربية السعودية. بار- اللوقـان، محمد فهاد (2016): أهميـة المتطلبـات اللازمـة لإنتاج المعرفـة كمدخل لبناء ميزة تتافسية في جامعـة حائل بالمملكـة العربيـة السعودية. مجلة العلوم التربوية: جامعة الملك سعود - كلية التربية، الرياض.

ـ ا- المربع، صالح بن سعد (2012): القيادة الاستراتيجية ودورها في تطوير الثقافة التنظيمية بالأجهزة الأمنية، جامعة نايف العربية للعلوم الأمنية، المملكة العربية السعودية. 10- المعاضيدي، معن (2007): إدارة المخاطر الاستراتيجية المسببة لفقدان المنظمة للمزايا التنافسية الآليات والمعالجات، دراسة نظرية تحليلية، مؤنمر إدارة المخاطر واقتصاد المعرفة،جامعة الزيتونة الخاصة، الأردن.

4ا - محمد، أحمد علي (2016): القيادة الاستراتيجية المحدة لفاعلية الإدارة العليا في جامعة النهرين، مجلة البحوث التربوية والنفسية، ع51. 


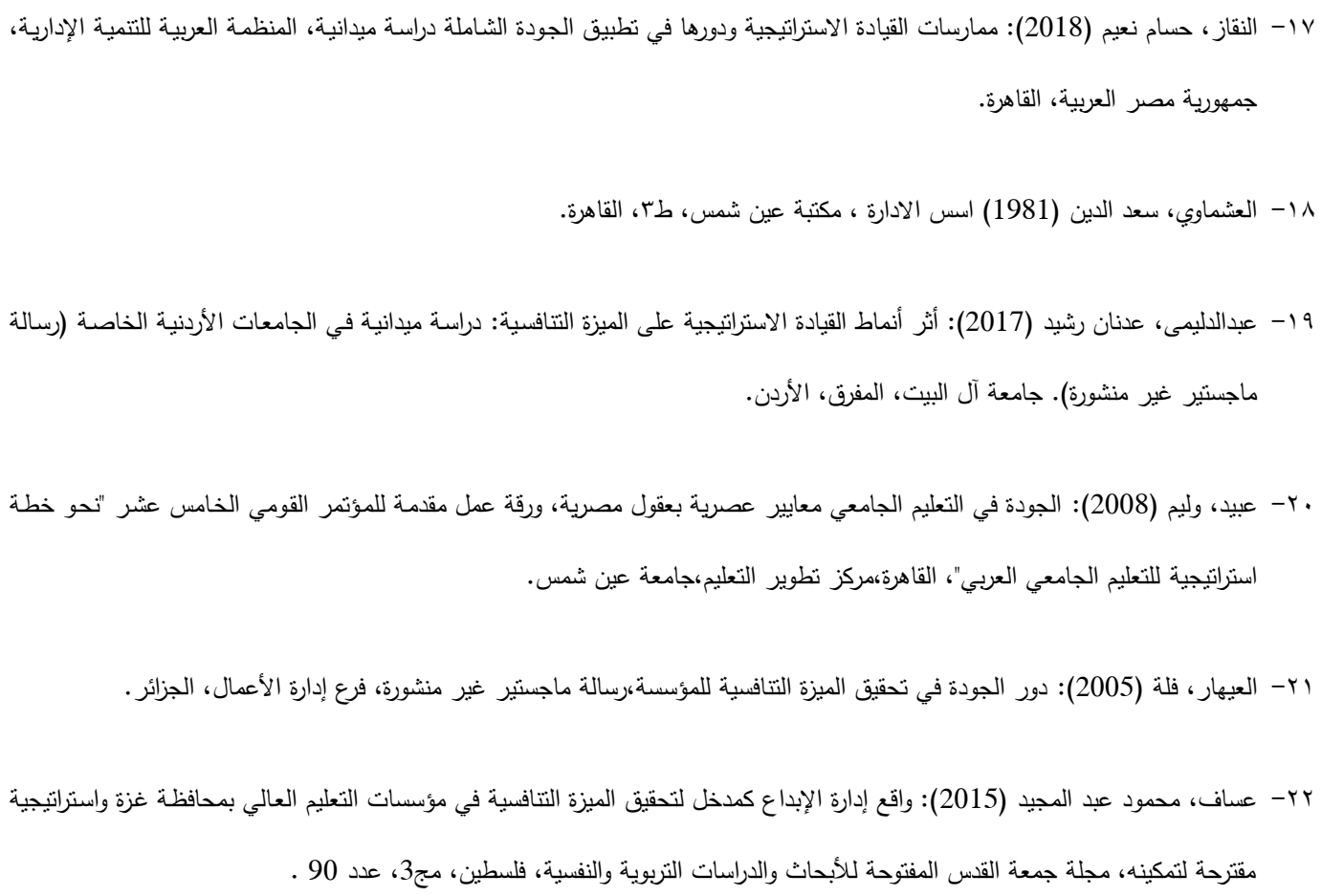

24- Bass, Benard M (2007), Executive and Strategic Leadership, International, Journal of Business, VOL. 12, NO. 1.

25- Essary, M. (2011) Exploring the Development of a Competitive Advantage model for Online Educatione in a small State University Unpublished Doctoral Dissertation, North central University. 
26- Hill, M. A., Ireland, R, D. \& Hoskisson, R. E. (2009) Strategic Management; Competitiveness and Globalization - Concepts and Cases $8^{\text {th }}$ ed, Thomson/ South Western, Ohio, USA.

27- Hughes, Richard L, \& Beatty, Katherine (2005) Becoming Astrategic Leader; your Role in your Organizations Enduring Success, John Wiley $\&$ Sons, Inc, USA.

28- Hill, Charles W. L \& Jones, Gareth R. (2010) Strategic management Theory; An Integrated Approach, $9^{\text {th }}$ Edition, South Western \& Cengage Learning, USA.

29- Hilcoat, R.A (1990), Strategic art the new art for $21^{\text {st }}$ Contury Leader, U.S. Army war college, Studies Institvte.

30- Mungonge, Goliath (2007), acase Study of Strategic eldershipinthe creation \& development of aprivately Owned news paper in Zambia, master of business administration.

31- Pisapia,John(2009), The strategic leader - new tacties for Globalizing World, Informaion Age Publishing, USA.

32- Ussahawanitcha Kit, P (2011) Moderating Effects of Environment on the Strategic Leadership, Organizational Learning, Innovation, and Performance Relationships, Journal of International Business and Economics,11(2), 13-99.

33- Wacher, Bend \& Neil, Kemp(2010):Internationally competitive Universities :Astudy for Academic Cooperation Association.

34- Youndt, M. A. Snell, S.A.Dean, J.W. \& Lepak, D.P (1996) Human Resource Management: Manufacturing Strategy \& firm Performance, Academy of Management, VOL. 39.

35-The Global Competitiveness Report 2010 - 2011@ 2010 World Economic Forum. 
